Atmos. Chem. Phys., 13, 10125-10141, 2013

www.atmos-chem-phys.net/13/10125/2013/

doi:10.5194/acp-13-10125-2013

(c) Author(s) 2013. CC Attribution 3.0 License.

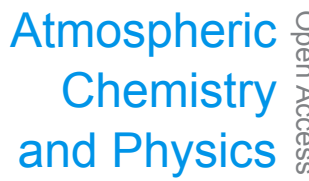

\title{
Chemical evolution of organic aerosol in Los Angeles during the CalNex 2010 study
}

\author{
R. Holzinger ${ }^{1}$, A. H. Goldstein ${ }^{2}$, P. L. Hayes ${ }^{3}$, J. L. Jimenez ${ }^{3}$, and J. Timkovsky ${ }^{1}$ \\ ${ }^{1}$ Institute for Marine and Atmospheric Research Utrecht, Utrecht University, the Netherlands \\ ${ }^{2}$ University of California, Berkeley, Dept. of Environmental Science, Policy, \& Management, Berkeley, California, USA \\ ${ }^{3}$ Cooperative Institute for Research in Environmental Sciences (CIRES) and Department of Chemistry and Biochemistry, \\ University of Colorado at Boulder, Boulder, Colorado, USA
}

Correspondence to: R. Holzinger (r.holzinger@uu.nl)

Received: 29 April 2013 - Published in Atmos. Chem. Phys. Discuss.: 15 May 2013

Revised: 3 September 2013 - Accepted: 4 September 2013 - Published: 15 October 2013

\begin{abstract}
During the CalNex study (15 May to 16 June 2010) a large suite of instruments was operated at the Los Angeles area ground supersite to characterize the sources and atmospheric processing of atmospheric pollution. The thermal-desorption proton-transfer-reaction massspectrometer (TD-PTR-MS) was deployed to an urban area for the first time and detected 691 organic ions in aerosol samples, the mean total concentration of which was estimated as $3.3 \mu \mathrm{g} \mathrm{m}^{-3}$. Based on comparison to total organic aerosol (OA) measurements, we estimate that approximately $50 \%$ of the OA mass at this site was directly measured by the TD-PTR-MS. Based on correlations with aerosol mass spectrometer (AMS) OA components, the ions were grouped to represent hydrocarbon-like OA (HOA), local OA (LOA), semi-volatile oxygenated OA (SV-OOA), and low volatility oxygenated OA (LV-OOA). Mass spectra and thermograms of the ion groups are mostly consistent with the assumed sources and/or photochemical origin of the OA components. The mass spectra of ions representing the primary components HOA and LOA included the highest $m / z$, consistent with their higher resistance to thermal decomposition, and they were volatilized at lower temperatures $\left(\sim 150^{\circ} \mathrm{C}\right)$. Photochemical ageing weakens $\mathrm{C}-\mathrm{C}$ bond strengths (also resulting in chemical fragmentation), and produces species of lower volatility (through the addition of functional groups). Accordingly the mass spectra of ions representing the oxidized OA components (SV-OOA, and LV-OOA) lack the highest masses and they are volatilized at higher temperatures $\left(250-300^{\circ} \mathrm{C}\right)$. Chemical parameters like mean carbon number $\left(\overline{n_{\mathrm{C}}}\right)$, mean carbon oxidation state $\left(\overline{\mathrm{OS}_{\mathrm{C}}}\right)$, and the
\end{abstract}

atomic ratios $\mathrm{O} / \mathrm{C}$ and $\mathrm{H} / \mathrm{C}$ of the ion groups are consistent with the expected sources and photochemical processing of the aerosol components. Our data suggest that chemical fragmentation gains importance over functionalization as photochemical age of OA increases. Surprisingly, the photochemical age of OA decreases during the daytime hours, demonstrating the importance of rapid production of new (photochemically young) SV-OOA during daytime. The PTR detects higher organic $\mathrm{N}$ concentrations than the AMS, the reasons for which are not well understood and cannot be explained by known artifacts related to PTR or the AMS. The median atomic $\mathrm{N} / \mathrm{C}$ ratio $(6.4 \%)$ of the ion group representing LV-OOA is a factor 2 higher than $\mathrm{N} / \mathrm{C}$ of any other ion group. This suggests a multiphase chemical source involving ammonium ions is contributing to LV-OOA.

\section{Introduction}

While the radiative forcing from greenhouse gases is reasonably understood and constrained, there are still major difficulties in quantifying the radiative forcing from aerosols (IPCC, 2007). A consequence of this shortcoming is the rather large range of possible climate sensitivities, which has been shown to hamper the accuracy of future climate projections (Andreae et al., 2005). Both the sources of aerosols and their climate effects are subject to major uncertainties. Goldstein and Galbally (2007) were the first to challenge low bottom-up estimates of the global source of secondary organic aerosols (SOA). Recent estimates of SOA 
formation still cover a wide range of $60-240 \mathrm{Tg} \mathrm{yr}^{-1}$ and it is equally uncertain what fraction of this should be attributed to natural vs. anthropogenic processes (Hallquist et al., 2009; Spracklen et al., 2011; Heald et al., 2011). This is especially uncertain when pollution (e.g. ozone, $\mathrm{NO}_{\mathrm{x}}, \mathrm{SO}_{2}$, or $\mathrm{NO}_{3}$ ) leads to enhanced SOA formation from biogenic volatile organic compounds (VOC).

Chemical reactions of organic precursor species in the gas or condensed phases lead to SOA formation. Semivolatile and/or low volatility compounds are produced by photooxidation of biogenic or anthropogenic precursors. The precursor compounds are mostly hydrocarbons (isoprene, monoterpenes, aromatics, alkanes) and to a lesser extent oxygenated hydrocarbons (e.g. Guenther et al., 2006; Jakober et al., 2008; Dzepina et al., 2009) to which functional groups (e.g. carbonyl, alcohol, nitrate, acid and others) are added, which decreases their saturation vapor pressure and increases their tendency to partition to the particle phase (e.g. Pankow and Asher, 2008). On the other hand, gas phase chemistry can also result in fragmentation (C-C bond cleavage) that breaks carbon chains producing smaller molecules with higher vapor pressures (Kroll et al., 2011). In order to model gasphase SOA formation the total organic mass in the atmosphere can be classified into saturation vapor pressure bins and their distribution between gas and aerosol phases is calculated according to absorptive partitioning (Donahue et al., 2006). This concept along with previously neglected precursors has been implemented in large atmospheric chemistry models and thus improved their skills in computing atmospheric evolution of organic aerosols (Hodzic et al., 2010), however, difficulties in properly modeling OA for the right reasons still remain.

Heterogeneous and multiphase processes in particles and cloud droplets are not yet properly represented in most atmospheric chemistry models, however, there is mounting evidence that they represent a significant pathway to SOA formation (Ervens et al., 2011). Evidence for oligomerization in particles was found several years ago (Kalberer et al., 2004). Small molecules such as glyoxal with several functional groups have been shown to rapidly produce secondary organic aerosol and thus must be very reactive when dissolved in the water phase of a particle (Volkamer et al., 2007). The heterogeneous formation of organosulfates from the originally inorganic pool of acidic sulfate has recently received attention (Surratt et al., 2008). In the same way organic nitrogen compounds in particles may be produced by chemistry of ammonium with organic compounds (Galloway et al., 2009). Although this nitrogen driven pathway of SOA formation is currently poorly constrained, multiphase chemistry involving ammonium may be of similar importance as organic nitrate partitioning into the particle phase, which has been shown to dominate nighttime SOA formation at some locations (Rollins et al., 2012).

During the past decade the wide application of Aerodyne aerosol mass spectrometers (AMS, Jayne et al., 2000) has led to progress on several atmospheric aerosol research questions, and these instruments are now commonly used in scientific field campaigns focusing on air pollution and atmospheric chemistry. AMS can quantify highly time resolved concentrations of sulfate, nitrate, ammonium, organics, and chloride in non-refractory aerosol below one micron diameter $\left(\mathrm{PM}_{1}\right)$. In the AMS the aerosol constituents are evaporated at high temperatures of $600{ }^{\circ} \mathrm{C}$ under high vacuum and subsequently ionized by means of electron ionization. Detailed chemical analysis is limited because both these processes produce a high degree of thermal decomposition and ion fragmentation. This deficiency is partly overcome by applying positive matrix factorization (PMF) to the measured mass spectra (Paatero and Tapper, 1994; Ulbrich et al., 2009), but information about the molecular constituents of aerosol cannot be recovered.

In this study we exploit the data from a relatively new instrument, the thermal-desorption proton-transfer-reaction mass-spectrometer (Holzinger et al., 2010a), which was operated next to an AMS during the CalNex campaign (Ryerson et al., 2013) in summer 2010 at the Pasadena ground site in the Los Angeles area of California. The TD-PTRMS uses relatively soft proton-transfer reactions for ionization and lower temperatures for evaporation of aerosol constituents $\left(50-350^{\circ} \mathrm{C}\right)$. Thus much more organic chemical information is preserved relative to the AMS. We focus on the comparison of AMS and TD-PTR-MS and our results illustrate the potential of TD-PTR-MS for elucidating different chemical pathways of aerosol formation.

\section{Experimental}

\subsection{The CalNex 2010 campaign}

In the framework of the California Research at the Nexus of Air Quality and Climate Change (CalNex) 2010 project, a field site was operated on the campus of the California Institute of Technology (Caltech) in Pasadena $\left(34.1408^{\circ} \mathrm{N}\right.$, $118.1223^{\circ} \mathrm{W}, 230 \mathrm{~m}$ a.s.1.), approximately $18 \mathrm{~km}$ northeast of downtown Los Angeles. Measurements were made from 15 May through 16 June 2010. More than 40 groups operated instruments at the site to characterize VOCs, semivolatile compounds, aerosol constituents, and additional gas phase species. Most instruments were operated in air conditioned containers that were grouped around two $10 \mathrm{~m}$ scaffolding towers onto which gas and aerosol inlets were mounted. An overview of the campaign including instrumentation at the ground sites and on mobile platforms is provided by Ryerson et al. (2013).

\subsection{The TD-PTR-MS instrument}

The TD-PTR-MS has been described by Holzinger et al. (2010a) and is referred to as "PTR" hereafter. For the measurements described here we used an instrument with 
a high mass resolution time-of-flight mass-spectrometer $(\mathrm{H}-$ TOF, Tofwerk AG) and a dual aerosol inlet (to increase the time resolution) that was operated as described in Holzinger et al. (2010b). The setup is shown in Fig. 1a. Briefly, ambient air is humidified and particles in the $0.07-2 \mu \mathrm{m}$ size range are collected by impaction on a Collection-Thermal-Desorption (CTD) cell. Aerosol compounds are thermally released from the CTD-cell by ramping the temperature up to $350^{\circ} \mathrm{C}$ in seven steps of $50^{\circ} \mathrm{C}$. Every temperature step is completed in three minutes and consists of a ramp and a dwell period of approximately 2 and $1 \mathrm{~min}$, respectively. A nitrogen carrier gas is used to transport desorbed aerosol compounds through heated transfer lines $\left(200^{\circ} \mathrm{C}\right)$ from the CTD cell to the detector, which is a commercial PTR-TOF-MS 8000 (Ionicon Inc. Austria). Figure 1b shows example timelines of the total product ion signal and $m / z 59.049$ over a full measurement cycle including gas phase and aerosol background measurements. As an organic species of $m / z 59.049$ is very unlikely to have been present in the aerosol, its signal is due to contamination from the gas phase, thermal decomposition of sampled aerosols on the CTD-cell, and/or fragmentation in the PTR during the process of ionization. The temperature steps of the CTD cell can be seen very clearly as sharp peaks in the mixing ratio (Fig. 1b) that decrease after the bulk of the material is volatilized at a temperature level. In this manner volatility information (i.e. thermograms) is obtained for each observed aerosol ion. Note that aerosol signals such as shown in Fig. $1 \mathrm{~b}$ are generally much higher than gas phase signals. This is due to amplification by sampling: aerosols of 250-400 L air are collected on the CTD-cell and desorbed into a flow of $7 \mathrm{~mL} \mathrm{~min}^{-1}$ (standard conditions), i.e. less than $0.15 \mathrm{~L}$ during a full analysis of $(21 \mathrm{~min})$ of the aerosol sample.

Specific conditions during field operation were as follows: $E / N=1.3 \times 10^{-19} \mathrm{~V} \mathrm{~m}^{2} \mathrm{molec}^{-1}$ (i.e. 130 Townsend units) to ensure ionization only by $\mathrm{H}_{3} \mathrm{O}^{+}$, temperature of the drift tube, $T_{\mathrm{d}}=120^{\circ} \mathrm{C}$, typical primary ion signal $5 \times 10^{5}$ counts per second, and a mass resolution of $m / \Delta m \approx 4000(\Delta m$ is full width at half maximum).

\subsection{Operation in the field}

At the Pasadena ground site, the PTR system was located in an air conditioned lab-container next to a $10 \mathrm{~m}$ scaffolding tower. Aerosols were sampled from the top of the scaffolding tower through a $12 \mathrm{~m}$ long copper line $(\mathrm{ID}=6.5 \mathrm{~mm})$. Coarse particles were removed by a $\mathrm{PM}_{2.5}$ cyclone $(10 \mathrm{Lpm}$, URG2000-30EN, URG Corporation, Chapel Hill, USA). The gas phase inlet was located next to the aerosol inlet and consisted of a $12 \mathrm{~m}$ PEEK tubing (ID $=1 \mathrm{~mm}$ ) of which the first $10 \mathrm{~m}$ were heated to a temperature of $150^{\circ} \mathrm{C}$. The flow through the gas inlet was maintained at $50 \mathrm{~mL} \mathrm{~min}^{-1}(\sim 12 \mathrm{~s}$ residence times) and the PTR sub-sampled from this flow at a

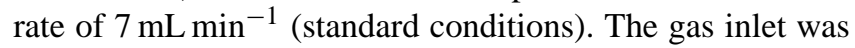
operated without a particle filter, so a significant fraction of aerosol mass was likely evaporated ( $\sim 50 \%$, see Huffman et al., 2009).

The operation of the system was fully automated and followed a fixed scheme that can be seen by the green, red, and brown bars below the $x$ axis in Fig. 1b. One cycle was completed in $90 \mathrm{~min}$ and included the analysis of the first (i) and second (ii) aerosol inlets, (iii) the analysis of ambient gas-phase (two periods of $10 \mathrm{~min}$ ), and (iv) the analysis of gas phase background (two periods of 5 and $10 \mathrm{~min}$, respectively), which was accomplished by leading ambient air through a platinum catalyst operated at $350^{\circ} \mathrm{C}$. The sampling flow for aerosol inlets A and B was 7 liters per minute (standard conditions), and the sampling time was 35 and $55 \mathrm{~min}$, respectively. After sampling the analysis was carried out without delay. The aerosol background was measured every other run by sampling through a Teflon membrane filter (Zefluor $2.0 \mu \mathrm{m}$, Pall Corp.) that removed the particles from the air stream. The remaining signal (inlet A in Fig. 1b) includes contamination from semivolatile gas phase compounds adhering to the CTD-cell or other sampling components, and instrumental background contamination. Filter samples to determine the aerosol background have been taken by turns: when inlet A sampled ambient air, inlet B sampled ambient air through the filter. In this way a time resolution of $90 \mathrm{~min}$ was achieved.

\subsection{The aerosol mass spectrometer (AMS)}

The concentrations of submicron non-refractory (NR-PM $\left.{ }_{1}\right)$ organic and inorganic (nitrate, sulfate, ammonium) aerosol particles were measured using a high resolution time-offlight aerosol mass spectrometer (HR-ToF-AMS, Aerodyne Research Inc., hereinafter AMS for short; DeCarlo et al., 2006), using the same H-TOF mass spectrometer from Tofwerk AG. The AMS sampled from an inlet equipped with a $\mathrm{PM}_{2.5}$ cyclone located $2 \mathrm{~m}$ above the roof of the container housing the instrument. The ambient air passed through a $6.8 \mathrm{~m}$ insulated copper inlet line and a drier prior to sampling by the AMS. The resulting data was averaged over 2.5 min intervals. All data were analyzed using standard AMS software (SQUIRREL v1.51 and PIKA v1.10) within Igor Pro 6.2.1 (Wave Metrics, Lake Oswego, OR; Sueper, 2011). High resolution analysis of the mass spectra was carried out following previously published procedures (DeCarlo et al., 2006; Aiken, et al., 2008; Hayes, et al., 2013). The accuracy of AMS OA is estimated at $30 \%$, and was verified with intercomparisons with multiple instruments (Hayes et al., 2013). The accuracy of the PMF components as fractions of the total $\mathrm{OA}$ is estimated at $10 \%$ of their concentrations. The accuracy of the AMS O/C, $\mathrm{H} / \mathrm{C}$, and $\mathrm{N} / \mathrm{C}$ is estimated as $31 \%$, $10 \%$, and $22 \%$, respectively (Aiken et al., 2008). AMS data were averaged to match the PTR sampling periods. 


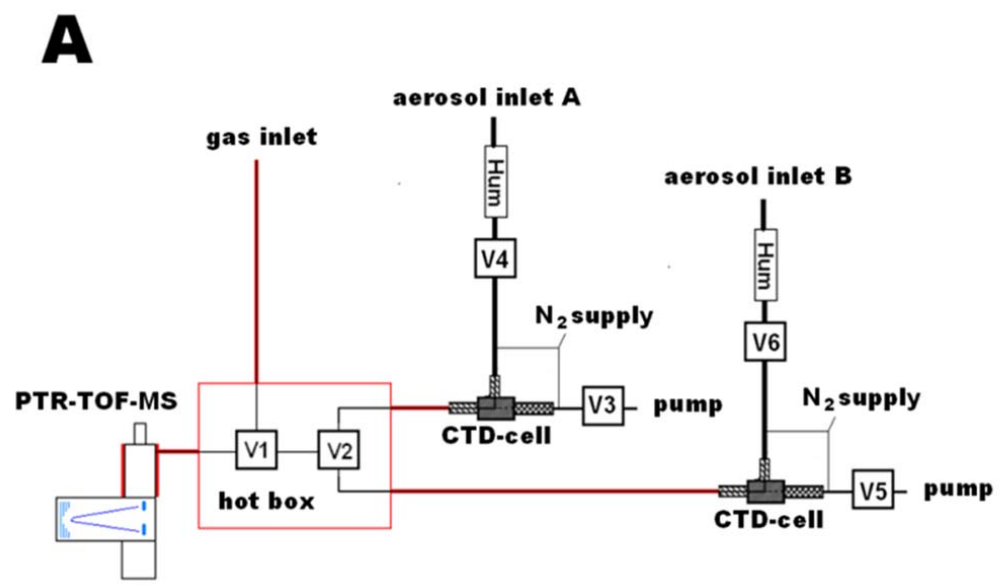

B

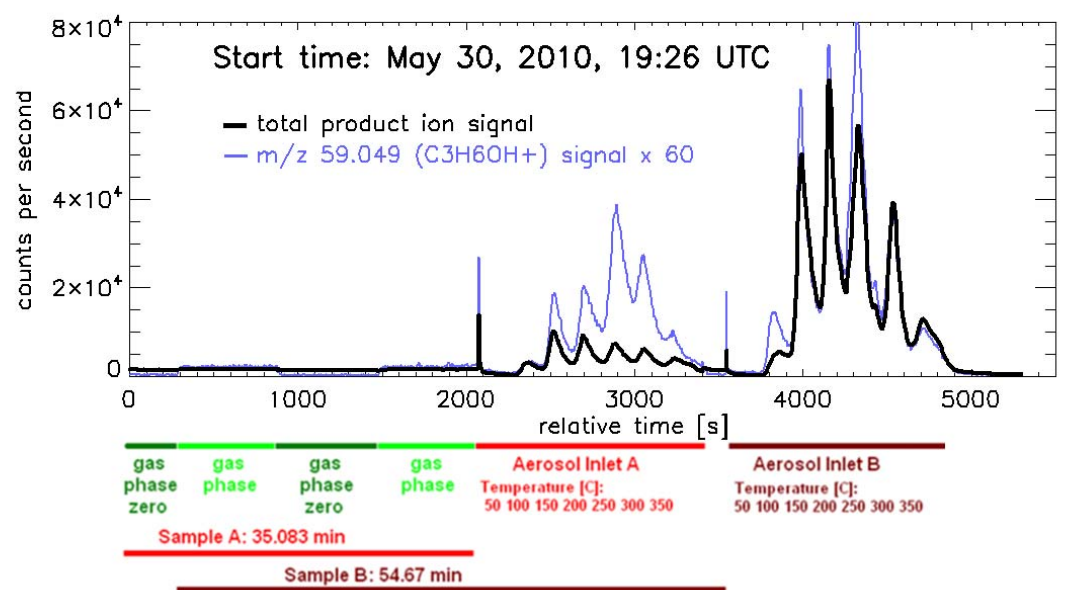

Fig. 1. Scheme of the TD-PTR-MS instrument (a). Chart (b) shows the operation during the CalNex study with example timelines of the total product ion signal and $m / z$ 59.049. The inlet A sampled through a particle filter while inlet B samples unfiltered ambient air.

\subsection{Basic data collection and processing (PTR)}

A time-of-flight spectrum was measured every $60 \mu$ s by pulsing ions into the spectrometer. The data acquisition parameters were set to save an average spectrum every $5 \mathrm{~s}$, which corresponds to averaging more than 83000 individual spectra. Each spectrum contains $\sim 3 \times 10^{5}$ data points and covers an $m / z$ 5-1278. 900 averaged $5 \mathrm{~s}$ mass spectra were saved into each file (i.e. $75 \mathrm{~min}$ of measurements) and approximately 500 data-files were collected throughout the campaign. Ambient air concentrations of detected ion species have been calculated according to the method outlined in Holzinger et al. (2010a). A default reaction rate constant of $3 \times 10^{-9} \mathrm{~cm}^{3} \mathrm{~s}^{-1}$ molecule ${ }^{-1}$ was used for proton transfer reactions in the PTR-MS drift tube, which has been established the best estimate for the average rate constant of aerosol species (Holzinger et al., 2010a, b). The use of a default reaction rate constant sets a limit to the accuracy of the reported mass concentration. Holzinger et al. (2010a) found that the value recommended by the manufacturer of the PTRTOF-MS $\left(2 \times 10^{-9} \mathrm{~cm}^{3} \mathrm{~s}^{-1}\right.$ molecule ${ }^{-1}$, Ionicon Inc., Austria) is too low and overestimates experimental SOA produced from ozonolysis of different terpenes roughly by $35 \%$. However, the average reaction rate constant may be different for different fractions of organic aerosol (OA), mainly due to differences in polarity and polarizability $(\mathrm{Su}$ and Chesnavich, 1982). Based on the reasonable agreement between TD-PTR-MS and SMPS derived aerosol concentrations in smog chamber studies (Holzinger et al., 2010a) and the uncertainty in reaction rate constants, we estimate the accuracy for reported total OA (i.e. the sum of all organic ions) and sub-fractions thereof to be within $\pm 30 \%$. The accuracy of single ion species has to be assessed individually for each ion but should be within $\pm 60 \%$ for the vast majority of ions. Note that these accuracy levels cover the detected fraction of OA. As will be discussed below, there are other losses of OA 
associated with fragmentation during ionization and thermal desorption.

Data processing was carried out according to the procedure described by Holzinger et al. (2010b) using custom made routines programmed in IDL (Interactive Data Language). The main data processing steps are (i) the calibration of the mass scale, (ii) peak detection, (iii) peak integration, and (iv) the correction for overlapping signals of species the separation of which is limited by the spectrometers' mass resolving power. A "unified mass list" has been created by evaluating the peak detection lists that have been created for each individual file $(n \approx 500)$. For example, the ion $\mathrm{C}_{3} \mathrm{H}_{6} \mathrm{OH}^{+}$ $(\mathrm{m} / z$ 59.049) is an omnipresent ion that is always detected in the PTR. Thus, the automated peak detection routine always detects this peak within the limits of the instrument precision. In order to establish the quality of peak detection we fitted the 500 measured $m / z$ values of the $\mathrm{C}_{3} \mathrm{H}_{6} \mathrm{OH}^{+}$ion with a normal distribution, the standard deviation $(\sigma)$ of which defines the precision of the measured $m / z$ value. For most mass peaks the precision was within 8-20 ppm; an example of this procedure is given in the Appendix (Fig. A2) and shows four peaks detected at $\mathrm{m} / z 113$ corresponding to $\mathrm{C}_{5} \mathrm{H}_{4} \mathrm{O}_{3} \mathrm{H}^{+}$, $\mathrm{C}_{6} \mathrm{H}_{8} \mathrm{O}_{2} \mathrm{H}^{+}, \mathrm{C}_{7} \mathrm{H}_{12} \mathrm{OH}^{+}, \mathrm{C}_{8} \mathrm{H}_{16} \mathrm{H}^{+}$, respectively. The larger uncertainties correspond to ions with low signal-to-noise ratios and for ions that could not be resolved well by the mass spectrometer. 924 ions have been added to the unified mass list for this experiment, representing all ions that have been commonly detected in the mass spectra.

\subsection{Attribution of empirical formulas}

A library has been created to attribute empirical formulas to the detected mass peaks. The library includes 400 hydrocarbons $\left(C_{1}-C_{40}\right.$, degree of unsaturation, $\left.\mathrm{DoU}=0-9\right), 3200$ oxygenated hydrocarbons $\left(\mathrm{O}_{1}-\mathrm{O}_{8}\right), 7200$ nitrogen containing organics $\left(\mathrm{N}_{1}-\mathrm{N}_{2}\right), 10800$ organosulfates, and $21600{ }^{13} \mathrm{C}$ species (i.e. all ions listed before with one ${ }^{13} \mathrm{C}$ isotope). In addition, all inorganic species that are commonly detected with the PTR were added to the library as well. We attributed all empirical formulas to a mass peak of which the difference in mass with the measured $m / z$ value was less than $\pm 2 \sigma$, or $\pm 2 \mathrm{mDa}$ if $2 \sigma$ was lower than this.

In a second step, we checked if the attributed formulas were consistent with the natural ${ }^{13} \mathrm{C} /{ }^{12} \mathrm{C}$ ratio of $\sim 0.011$. For example, if a ${ }^{13} \mathrm{C}$ compound has been attributed to a mass peak, consistency with the signal of the parent compound (i.e. the same empirical formula with only ${ }^{12} \mathrm{C}$ isotopes) was checked. An empirical ${ }^{13} \mathrm{C}$-formula was attributed if one of the following criteria were matched: (i) the ${ }^{13} \mathrm{C}$ compound was the only empirical formula attributed to the mass peak AND the expected value (calculated from the ${ }^{12} \mathrm{C}$ parent compound) is at least $50 \%$ of the measured signal, or (ii) besides the ${ }^{13} \mathrm{C}$ compound there were other possible empirical formulas (e.g. N-compounds) AND the expected value is at least $20 \%$ of the measured signal.

\subsection{Determination of aerosol species and preparation of the final dataset}

The aerosol signal has been computed for all detected ions by subtracting the signal of the filtered ambient air sample from the signal of the unfiltered sample. The closest filtered sample of the respective aerosol inlet was used as background and the subtraction was done point by point for each temperature level. An example of aerosol signal and background for species detected at $m / z 125.059$ is given in the Appendix (Fig. A1). For the bulk of the ions the background signal was typically less than 10-20\% of the aerosol signal. However, for a limited number of ions the background level was much higher due to contamination from semivolatile gas phase compounds. An example is $m / z 59.049$ that exhibited very high background levels. In Fig. $1 \mathrm{~b}$ this can be seen by very high mixing ratios measured at Inlet A, which was operated in the background mode.

The computed aerosol signal of a detected ion was considered significantly enhanced if its mean value in the period 3-9 June 2010, was larger than 3 sigma (i.e. the standard deviation of all background measurements of the same period) for two or more temperature levels. 748 ions fulfilled this criterion. The total aerosol signal of each ion has been calculated as the sum of the signal at all temperatures. This dataset is available at the CalNex data download site ${ }^{1}$ and forms the basis of the analysis presented below.

\subsection{Calculation of chemical parameters}

For the analysis presented below we calculated the following chemical parameters: the mean carbon number $\left(\overline{n_{\mathrm{C}}}\right)$, the mean oxidation state of carbon $\left(\overline{\mathrm{OS}_{\mathrm{C}}}\right)$, and the atomic ratios $\mathrm{O} / \mathrm{C}, \mathrm{H} / \mathrm{C}$, and $\mathrm{N} / \mathrm{C}$.

We used the attributed empirical formulas as basis for these calculations. In case of more than one possible formula we made following choices as for which empirical formula was used: (i) we did not use sulfate species because we consider their attribution rather uncertain, (ii) we dismissed nitrogen species whenever there was a possible empirical formula without nitrogen. The latter assumption may result in an underestimation of $\mathrm{N}$-species. There were many ions at $\mathrm{m} / \mathrm{z}$ that allowed alternative attributions with a $\mathrm{N}_{1}$-compound and a CHO compound containing a ${ }^{13} \mathrm{C}$-isotope. According to the rules outlined above, the ${ }^{13} \mathrm{C}$-species was attributed if the signal of the corresponding parent species suggested that at least $20 \%$ of the signal could be attributed to this isotope, but for the chemical analysis we attributed $100 \%$ of the signal to this species. Similarly, for many possible $\mathrm{N}_{2}$-formulas there were alternative formulas without nitrogen in which case the nitrogen containing formula has been dismissed. Nevertheless, 164 and 24 ion species were attributed to empirical formulas containing 1 and 2 nitrogens, respectively.

\footnotetext{
${ }^{1}$ http://www.esrl.noaa.gov/csd/groups/csd7/measurements/ 2010calnex/Ground/DataDownload/
} 
The mean carbon number, $\overline{n_{\mathrm{C}}}$, is calculated according to

$$
\begin{aligned}
& \overline{n_{\mathrm{C}}}=\frac{1}{[\mathrm{TOT}]} \sum_{i}\left(\frac{[\text { species }]_{i} n_{\mathrm{C}_{i}}}{\mathrm{MW}_{i}}\right), \\
& \text { with }[\mathrm{TOT}]=\sum_{i} \frac{[\text { species }]_{i}}{\mathrm{MW}_{i}},
\end{aligned}
$$

where $[\mathrm{TOT}]$ and $[\text { species }]_{i}$ represent time series vectors of the total measured concentration $\left(\mu \mathrm{mol} \mathrm{m}^{-3}\right)$ and the concentration of species $i\left(\mu \mathrm{g} \mathrm{m}^{-3}\right)$, respectively. $\mathrm{MW}_{i}$, and $n_{\mathrm{C}_{i}}$ represent the molecular weight (in $\mathrm{g} \mathrm{mol}^{-1}$ ), and number of carbon atoms of species $i$, respectively. The atomic ratio $\mathrm{O} / \mathrm{C}$ is calculated according to

$$
\mathrm{O} / \mathrm{C}=\frac{\sum_{i}\left(\frac{\left[\text { species }_{i} n_{\mathrm{O}_{i}}\right.}{\mathrm{MW}_{i}}\right)}{\sum_{i}\left(\frac{\left[\text { species }_{i} n_{\mathrm{C}}\right.}{\mathrm{MW}_{i}}\right)},
$$

where $n_{\mathrm{O}_{i}}$ and $n_{\mathrm{C}_{i}}$ represent the number of oxygen and carbon atoms of species $i$, respectively. The calculation of $\mathrm{H} / \mathrm{C}$ and $\mathrm{N} / \mathrm{C}$ is equivalent. The mean carbon oxidation state $\left(\overline{\mathrm{OS}_{\mathrm{C}}}\right)$ is calculated according to

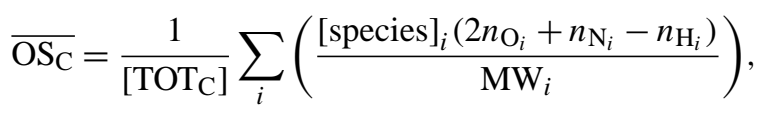

with $\left[\mathrm{TOT}_{\mathrm{C}}\right]=\sum_{i} \frac{[\text { species }]_{i} n_{\mathrm{C}_{i}}}{\mathrm{MW}_{i}}$

where $\left[\mathrm{TOT}_{\mathrm{C}}\right]$ represents the time series vectors of the total measured concentration of carbon atoms $\left(\mu \mathrm{mol} \mathrm{m}^{-3}\right)$, and $n_{\mathrm{N}_{i}}$ and $n_{\mathrm{H}_{i}}$ represent the number of nitrogen and hydrogen atoms of ion $i$, respectively. The equation to calculate $\overline{\mathrm{OS}_{\mathrm{C}}}$ is an approximation because fixed oxidation states of $-2,-1$ and +1 are assumed for oxygen, nitrogen and hydrogen (Kroll et al., 2011). This is not correct for peroxide groups in which the oxidation state of oxygen is -1 . The oxidation state of nitrogen is in many cases different from -1 and can vary largely from -3 to +5 . However, the empirical formulas of nitrogen species suggest that these species are rather reduced and an average nitrogen oxidation state of -1 is a good approximation. The uncertainty in the nitrogen oxidation state introduces only minor biases $(90 \%$ of the calculated $\overline{\mathrm{OS}_{\mathrm{C}}}$ values shift less than 0.06 and 0.14 for nitrogen oxidation states of -2 and 0 , respectively) and the analysis presented below (especially the slopes presented in Fig. 6) is not sensitive to variations of the assumed oxidation state of nitrogen within the boundaries of -2 and 0 . Similarly, peroxides are formed under low- $\mathrm{NO}_{\mathrm{x}}$ conditions and are not expected to represent a substantial oxygen fraction in OA in Los Angeles where high- $\mathrm{NO}_{\mathrm{x}}$ chemistry dominates and therefore, we are confident that $\overline{\mathrm{OS}_{\mathrm{C}}}$ is calculated with sufficient accuracy. The summations applied in Eqs. (1-3) can be over all detected organic species or over sub-groups thereof.

\section{Results and discussion}

\subsection{Total organic signal from PTR and AMS}

The PTR detected 691 organic ions due to organic species in aerosols. Each ion may be composed of several structural isomers with the same elemental composition. An ion was tagged organic when its $m / z>100$, or (for ions with $m / z<100$ ) when the attributed empirical formula indicated an organic species. The total signal of aerosol organics has been computed as the sum of the 691 organic ions and is referred to as PTR-OA hereafter. Figure 2 shows the time series and scatter plot of PTR-OA and AMS OA throughout the campaign. The concentrations are correlated $\left(r^{2}=\right.$ 0.60 , Pearson's correlation coefficient is used throughout this work). The mean total concentration of PTR-OA was $3.3 \mathrm{\mu g} \mathrm{m}^{-3}$, and the $10 \%, 50 \%$, and $90 \%$ percentiles where $0.6,2.2$, and $7.3 \mu \mathrm{g} \mathrm{m}^{-3}$, respectively. For AMS-OA the equivalent values were $6.9,2.5,6.2$, and $12.4 \mu \mathrm{g} \mathrm{m}^{-3}$, respectively. The lower concentrations from PTR are not surprising. Known loss processes are discussed in Holzinger et al. (2010a, b) and include (i) the fragmentation of aerosol species during the process of protonation (the mass of the neutral fragment is not measured, unlike in the AMS in which it can still be accounted for due to the properties of electron ionization, see Jimenez et al., 2003), (ii) thermal decomposition during the heating of the CTD cell that also produces undetectable species such as $\mathrm{CO}_{2}, \mathrm{H}_{2} \mathrm{O}$ and nonvolatile residue (charring) that is not volatilized at $350^{\circ} \mathrm{C}$. On the other hand, thermal decomposition produces many products (e.g. acetone, acetaldehyde, formic acid and many others) that are very well detected by PTR and in this sense thermal decomposition helps to detect low/nonvolatile aerosol mass that would otherwise not desorb from the CTD cell.

Contamination of the CTD cell with gas phase compounds in combination with the selection criteria to select aerosol compounds (as outlined above) may also produce biases towards lower PTR-OA concentrations. For example $\mathrm{C}_{2} \mathrm{H}_{4} \mathrm{OH}^{+}$is certainly produced as thermal composition product from OA. However, the mean aerosol signal was lower than 3 sigma of the background signal and thus this ion has not been tagged an aerosol compound since this selection criteria was not matched. This is important because whole compound groups such as alkanes may have been excluded. In the PTR alkanes larger than $\mathrm{C}_{8}$ fragment to produce $\mathrm{C}_{3} \mathrm{H}_{7}^{+}, \mathrm{C}_{4} \mathrm{H}_{9}^{+}, \mathrm{C}_{5} \mathrm{H}_{11}^{+}$and $\mathrm{C}_{6} \mathrm{H}_{13}^{+}$(Jobson et al., 2005). During CalNex high signals have been measured at the respective $m / z$ ratios, but only the $\mathrm{C}_{6} \mathrm{H}_{13}^{+}$was tagged an aerosol compound. The aerosol signal of the other ions was not significantly above the background, which means that there was a significant interference with gas phase compounds. However, this effect is not thought to be large enough to account for the whole difference between PTR and AMS OA.

An additional reason is the relatively low thermal desorption temperature $\left(350^{\circ} \mathrm{C}\right)$ in the PTR, which does not 


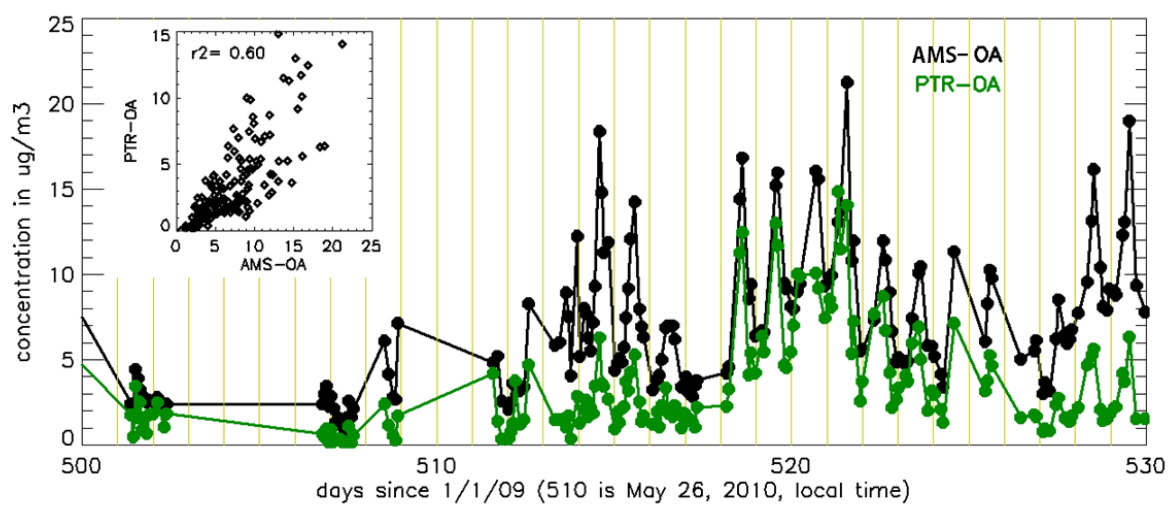

Fig. 2. Course of the concentrations of total organics measured with TD-PTR-MS and AMS. The insert shows a scatter plot of AMS-OA and PTR-OA.

guarantee $100 \%$ evaporation efficiency. The latter may be an important reason for lower PTR signals because evaporation occurs at $600^{\circ} \mathrm{C}$ in the AMS. Indeed when the AMS vaporizer was operated at $350^{\circ} \mathrm{C}$ during the SOAR-2005 study in the Los Angeles Basin, the AMS detected about half of the mass than when operated at $600^{\circ} \mathrm{C}$ (Docherty et al., 2008). However, a thermal denuder reduced the OA signal by $90 \%$ when operated at $225^{\circ} \mathrm{C}$ during the same study (Huffman et al., 2009). The latter suggests that the limit of $350^{\circ} \mathrm{C}$ does not significantly constrain the detection of $\mathrm{OA}$ in the PTR, however overall this indicates that the fraction of material evaporated depends strongly on the physical system and timescale (minutes for TD-PTR-MS, seconds for thermodenuder, and milliseconds for AMS) used for particle evaporation.

\subsection{Correlation of PTR ions with OA components}

Five OA components have been derived from PMF analysis on the AMS data (Hayes et al., 2013). These are hydrocarbon-like OA (HOA), cooking-influenced OA (CIOA), local OA (LOA), semi-volatile and low volatility oxygenated OA (SV-OOA, and LV-OOA). Here we explore the correlation of the 691 organic ions with the AMS-PMF OA components. In fact, for all ion species we correlated the signal measured at the 6 temperature levels of the CTD-cell $\left(100,150,200,250,300\right.$, and $\left.350^{\circ} \mathrm{C}\right)$, summing up to 4146 $(691 \times 6)$ time series that were correlated to the 5 OA components plus total OA from the AMS. A summary of this analysis is shown in Fig. 3 and Tables A1-A7 in the Supplement.

For 1124 of these time series the correlation coefficient $\left(r^{2}\right)$ did not exceed 0.3 for any of the five OA components or AMS-OA (about $12 \%$ of the detected mass). These were mostly time series with high noise levels due to very low signals and/or high background levels (e.g. $85 \%$ of these data were at the 100,300 , and $350^{\circ} \mathrm{C}$ level where the signals were typically very low, and the instrumental background maxi- mized at 300 and $350{ }^{\circ} \mathrm{C}$ ) and were excluded from further analysis.

The signal of 481 ions (1370 time series) summing up to about $40 \%$ of total PTR-OA mass (referred to as OA-ions hereafter) correlated better with AMS-OA than with any of the AMS-PMF components. The OA-ions likely originate from different OA components. Therefore, their correlation is best with total AMS-OA. Figure $3 \mathrm{f}$ and 1 show the time series and diurnal cycle of OA-ions during the campaign together with AMS-OA, respectively. These ions have indeed a similar diurnal cycle and time series as total AMS-OA, and account for $\sim 25 \%$ of the mass of AMS-OA between 4 a.m. and 3 p.m., and for a smaller fraction of $\sim 15 \%$ in the evening hours. The signal of 434 ions (765 time series; $\sim 20 \%$ of PTR-OA) correlated best with HOA (Fig. 3a and g) and are referred to as HOA-ions hereafter. The HOA-ions account roughly for the entire HOA signal between 4 a.m. and 3 p.m. and for $50-80 \%$ during evening and night. The reason for the diurnal bias is currently not understood. This suggests that the PTR is detecting hydrocarbons efficiently and that losses of signal due to e.g. fragmentation are minor. 208 ions (511 time series; 20\% of PTR-OA) correlated best with LV-OOA. The LV-OOA-ions account for $\sim 40 \%$ of the LV-OOA signal and no clear bias in the diurnal pattern is observed (Fig. 3e and k). 116 ions (226 time series; $\sim 4 \%$ of PTR-OA) correlated best with SV-OOA. The SV-OOA-ions account for $\sim 5 \%$ of the SV-OOA signal during day ( 6 a.m.6 p.m.) and slightly more $(\sim 7 \%)$ during night (Fig. $3 \mathrm{~d}$ and j). 100 ions (136 time series; $~ 3 \%$ of PTR-OA) correlated best with LOA. The LOA-ions account for $20-30 \%$ of the LOA signal and no clear bias in the diurnal pattern is observed (Fig. $3 \mathrm{c}$ and i). Only 10 ions (14 time series) correlated best with CIOA. The CIOA-ions constituted less than $0.3 \%$ of PTR-OA and less than $1 \%$ of CIOA (Fig. $3 \mathrm{~b}$ and h). Therefore, we excluded this group from further analysis.

Figure 4 shows normalized mass spectra (campaign mean) of PTR-OA, HOA-ions, LOA-ions, SV-OOA-ions, and LVOOA-ions. Ions constituting PTR-OA cover the mass range 

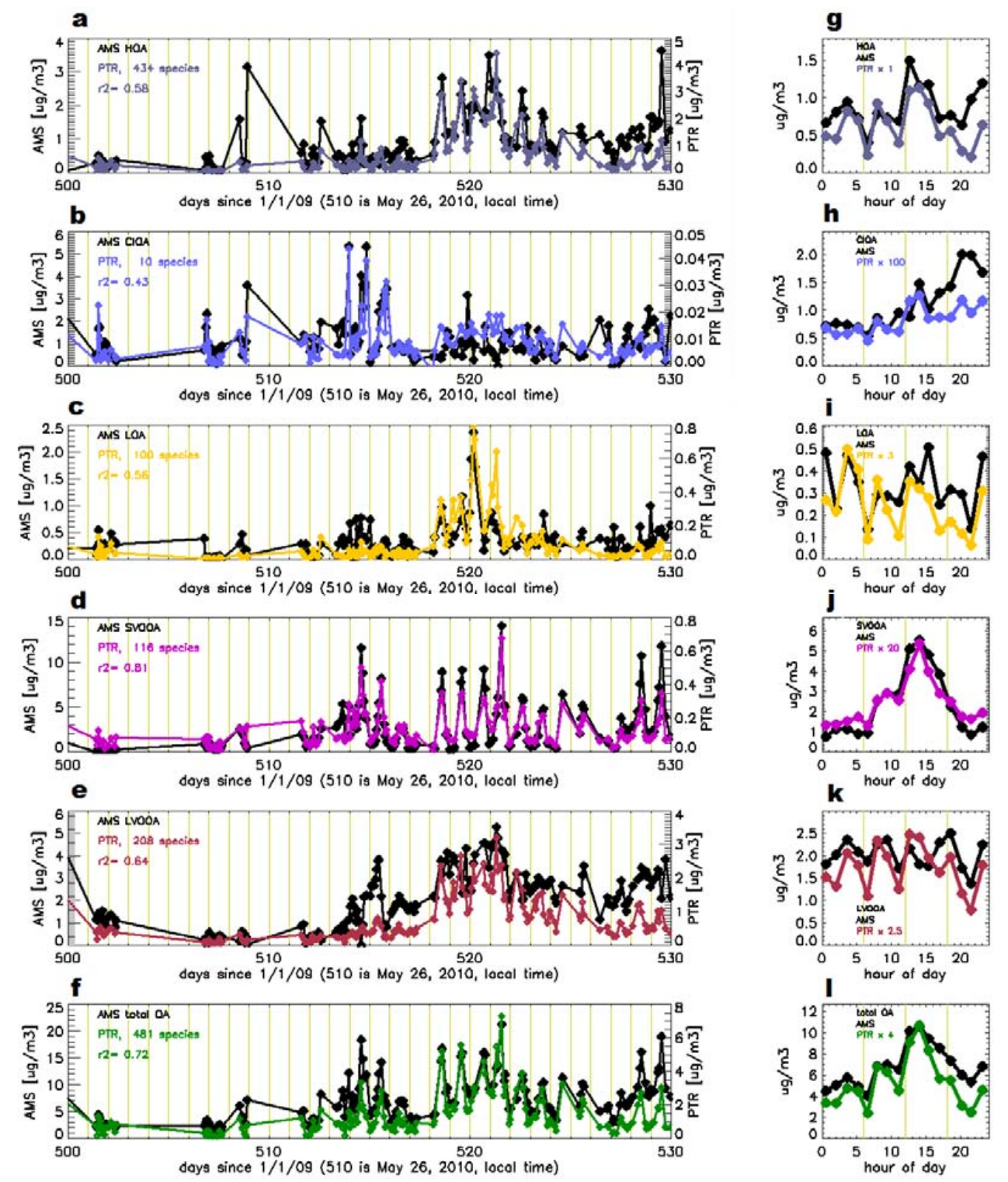

Fig. 3. Timelines of HOA, CIOA, LOA, SV-OOA, LV-OOA, and OA together with the groups of ions best correlating with these components, respectively (a-f). Campaign-mean diurnal cycle of the same $(\mathbf{g}-\mathbf{l})$.

$m / z$ 30-500, with ions in the mass range 90-170 constituting the bulk of PTR-OA (note that this is the total PTR-OA signal and not just the OA-ions). The weighted mean $\mathrm{m} / \mathrm{z}$ of HOA-ions is 199. HOA-ions include many ions in the range 350-500, and ions below 100 are present at low relative fractions with respect to the other groups. LOA-ions encompass the entire mass spectrum and their weighted mean $\mathrm{m} / \mathrm{z}$ is 205. Only 4 ions, $\mathrm{C}_{10} \mathrm{H}_{14} \mathrm{OH}^{+}, \mathrm{C}_{10} \mathrm{H}_{16} \mathrm{OH}^{+}, \mathrm{C}_{16} \mathrm{H}_{32} \mathrm{O}_{2} \mathrm{H}^{+}$, and $\mathrm{C}_{16} \mathrm{H}_{22} \mathrm{O}_{4} \mathrm{H}^{+}$, constitute $28 \%$ of the LOA signal (Table A3). The group of SV-OOA-ions lacks ions above 350; their weighted mean $m / z$ is 181 . The group of LV-OOA-ions is the lightest and lacks ions above 230; their weighted mean $m / z$ is 107 .
Compounds with a molecular weight of $100 \mathrm{amu}$ and below are not expected to partition to the particle phase because their vapor pressure is too high. Therefore, we consider all ions of $\mathrm{m} / \mathrm{z} 100$ and below to be fragments of the original aerosol molecules. As discussed above, fragmentation can occur on the CTD-cell (referred to thermal decomposition hereinafter) and during the process of ionization in the PTR. The spectra shown in Fig. 4 bear some similarity to those from the AMS, in the sense that the primary HOA show larger $m / z$ values than SV-OOA and LOA followed by LV-OOA that almost completely lacks $m / z$ values above 90 (Hayes et al., 2013). This is thought to be due to the higher resistance to thermal decomposition of HOA with respect to 


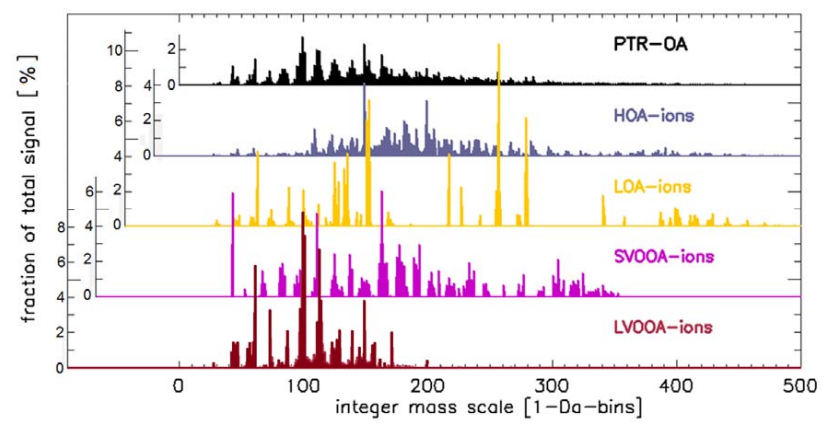

Fig. 4. Mass spectra of PTR-OA and the sub-fractions of ions correlating best with HOA, LOA, SV-OOA, and LV-OOA.

the other components, whereas LV-OOA is thought to thermally decompose more easily. With this correspondence we tentatively interpret ions below $\mathrm{m} / \mathrm{z} 100$ to be dominated by thermal decomposition in the CTD cell rather than to fragmentation occurring during ionization in the PTR.

Figure 5 shows the fraction of the total signal desorbed at the different temperature levels of the CTD-cell (thermogram) for the different ion groups. The HOA- and LOA-ions mostly desorb at lower temperatures. The largest fraction desorbs at $150{ }^{\circ} \mathrm{C}$; more than $90 \%$ of the mass is desorbed at temperatures below $200^{\circ} \mathrm{C}$. In contrast, over $95 \%$ of the mass of SV-OOA-ions is desorbed at temperatures of $250^{\circ} \mathrm{C}$ and above, with a maximum at $300^{\circ} \mathrm{C}$. Surprisingly (and to be discussed below), the LV-OOA-ions desorb at much lower temperatures: over $70 \%$ of their mass is desorbed at temperatures of $200^{\circ} \mathrm{C}$ and below.

Compounds constituting newly formed SOA are relatively volatile and consist of long chained molecules, which is consistent with the observed mass spectra and thermograms of HOA- and LOA-ions. AMS derived $\mathrm{O} / \mathrm{C}$ ratios are 0.14 and 0.31 for HOA and LOA, respectively, suggesting that these fractions might also contain first generation oxidation products of primary anthropogenic and - less likely - biogenic hydrocarbons, besides some oxidized primary species (Hayes et al., 2013). As organic species further age in air, more functional groups are added and chains are broken up so that the size of the molecules decreases. Overall, as atmospheric oxidation proceeds a pool of semivolatile compounds with a reduced average molecular weight is produced. Oxidation favors also the partitioning of smaller molecules to the particle phase, and finally oxidized species are more prone to thermal decomposition than reduced species. A combination of these 3 reasons likely explains the lower mean $\mathrm{m} / \mathrm{z}$ of SV-OOA-ions and the fact that none of the highest masses detected was attributed to this group. It could be expected that LV-OOA-ions would desorb at even higher temperatures than SV-OOA ions. However the opposite is observed. PMF analysis on thermodenuder-AMS data from 2 field campaigns (MILAGRO and SOAR-2005) showed that LV-OOA is less volatile than SV-OOA, and that $\sim 90 \%$ of SV-OOA is

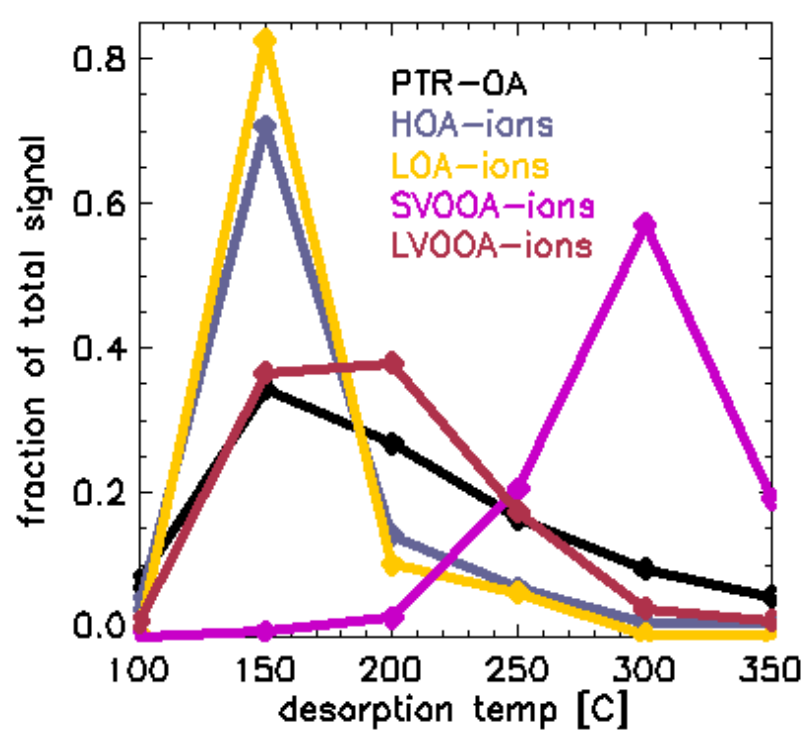

Fig. 5. Thermograms of PTR-OA and the sub-fractions of ions correlating best with $\mathrm{HOA}$, LOA, SV-OOA, and LV-OOA, respectively.

volatilized at a denuder temperature of $200^{\circ} \mathrm{C}$ (Huffman et al., 2009). This suggests that the thermogram of SV-OOAions is not representing the thermogram of the 'real' SVOOA component. Indeed, if we repeat the analysis above and correlate the PTR ions only with the AMS-PMF components (i.e. excluding AMS-OA), the group of SV-OOA-ions becomes larger, accounting for $40 \%$ of SV-OOA, while the other groups do not change significantly. As a consequence, the thermogram of SV-OOA-ions shifts towards lower temperatures with fractions of the total signal of $29 \%, 34 \%$, and $25 \%$ at temperatures of $200^{\circ} \mathrm{C}, 250^{\circ} \mathrm{C}$, and $300^{\circ} \mathrm{C}$, respectively. This shows that the analysis performed above rather identifies the best ion markers of SV-OOA than extracting a quantitative representation of this component. To a lesser extent this may also hold for the other groups, but only minor changes were observed when carrying out the same analysis for HOA-, LOA-, and LV-OOA-ions. However, even the extended group of SV-OOA ions desorbs at higher temperatures than the group of LV-OOA-ions. Together with the fact that weighted mean $m / z$ of LV-OOA-ions (107) is much lower than for SV-OOA-ions (181) we conclude that other physicochemical processes than volatility dominate the desorption of LV-OOA-ions. The higher O / C ratio (0.799 and 0.384 for LV-OOA and SV-OOA, respectively, Hayes et al., 2013) of LV-OOA may favor stronger thermal decomposition of this OA fraction because in general oxygen functional groups remove electron density from neighboring carbons, thereby weakening the $\mathrm{C}-\mathrm{C}$ bonds. Note that thermal desorption occurred under a pure $\mathrm{N}_{2}$ atmosphere, so thermal decomposition could also be limited by the availability of oxygen. Desorption under different geometries (isolated particles in air vs. multilayer deposits of particles in a surface), 


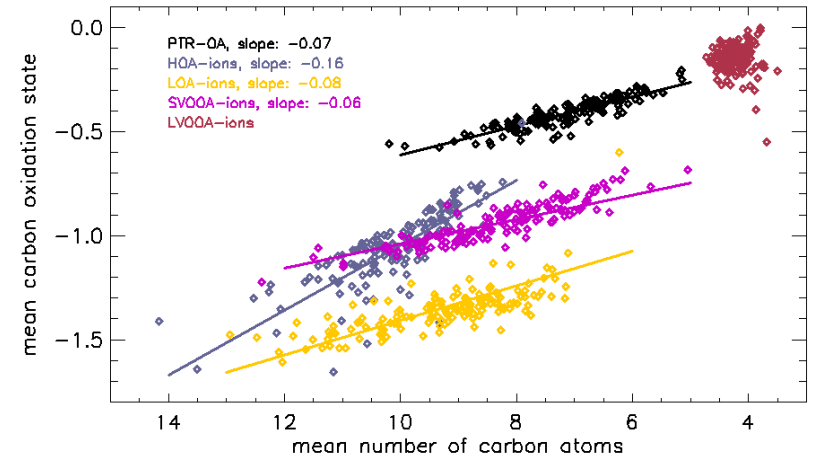

Fig. 6. Scatter plot of the chemical parameters $\overline{n_{\mathrm{C}}}$ and $\overline{\mathrm{OS}_{\mathrm{C}}}$ of PTR$\mathrm{OA}$ and the sub-fractions of ions correlating best with HOA, LOA, SV-OOA, and LV-OOA, respectively.

atmospheres (air vs. $\mathrm{N}_{2}$ ), and possibly different timescales (seconds vs. minutes) may explain the very different thermograms obtained by thermodenuder-AMS experiments (Huffman et al., 2009) and PTR.

\subsection{Chemical evolution of PTR-OA}

The chemical evolution of PTR-OA and fractions thereof are discussed on basis of the chemical parameters $\overline{n_{\mathrm{C}}}, \overline{\mathrm{OS}_{\mathrm{C}}}$, $\mathrm{O} / \mathrm{C}$, and $\mathrm{H} / \mathrm{C}$. Figure 6 shows $\overline{n_{\mathrm{C}}}$ versus $\overline{\mathrm{OS}_{\mathrm{C}}}$ for PTROA, HOA-, LOA-, SV-OOA-, and LV-OOA-ions. Figure 7 shows $\mathrm{O} / \mathrm{C}$ versus $\mathrm{H} / \mathrm{C}$ (van Krevelen diagram) of the same PTR groups together with $\mathrm{O} / \mathrm{C}$ and $\mathrm{H} / \mathrm{C}$ values of AMS$\mathrm{OA}$ and the constant atomic ratios (PMF-derived) of HOA, LOA, SV-OOA, and LV-OOA. Figure 8 shows the median diurnal cycle of the 4 chemical parameters for HOA-, LOA, SV-OOA-, and LV-OOA-ions. For each time-bin in Fig. 8, 7-13 data points from individual days were available. We removed the two most outlying points and plotted the median ( \pm standard deviation) of the remaining 5-11 data points.

The chemical parameters are derived based on correlation of a large suite of ions the signals of which were entirely attributed to HOA, LOA, SV-OOA, and LV-OOA. The concentrations of the ions in each ion-group change in time, and this variability leads to the changes in $\overline{n_{\mathrm{C}}}, \overline{\mathrm{OS}_{\mathrm{C}}}, \mathrm{O} / \mathrm{C}$ and $\mathrm{H} / \mathrm{C}$ that are observed for each of the ion-groups in Figs. 6 and 7. This is different than for the AMS-PMF components that have fixed (average) spectra and are represented by single points in the van Krevelen diagram (Fig. 7).

Kroll et al. (2011) suggested using $\overline{n_{\mathrm{C}}}$ and $\overline{\mathrm{OS}_{\mathrm{C}}}$ as a metric for describing the chemistry of atmospheric OA. Primary organic aerosol consists of relatively large and reduced molecules. In the $\overline{n_{\mathrm{C}}}-\overline{\mathrm{OS}_{\mathrm{C}}}$ space (Fig. 6) primary OA occupies a region near the left bottom corner (large $\overline{n_{\mathrm{C}}}$ and low $\overline{\mathrm{OS}_{\mathrm{C}}}$ values). As $\mathrm{OA}$ ages the chemical composition changes as organic species are oxidized $\left(\overline{\mathrm{OS}_{\mathrm{C}}}\right.$ increases $)$ and longer carbon chains are broken up ( $\overline{n_{\mathrm{C}}}$ decreases $)$. Thus, aged OA occupies a region near the right top corner (low $\overline{n_{\mathrm{C}}}$ and large

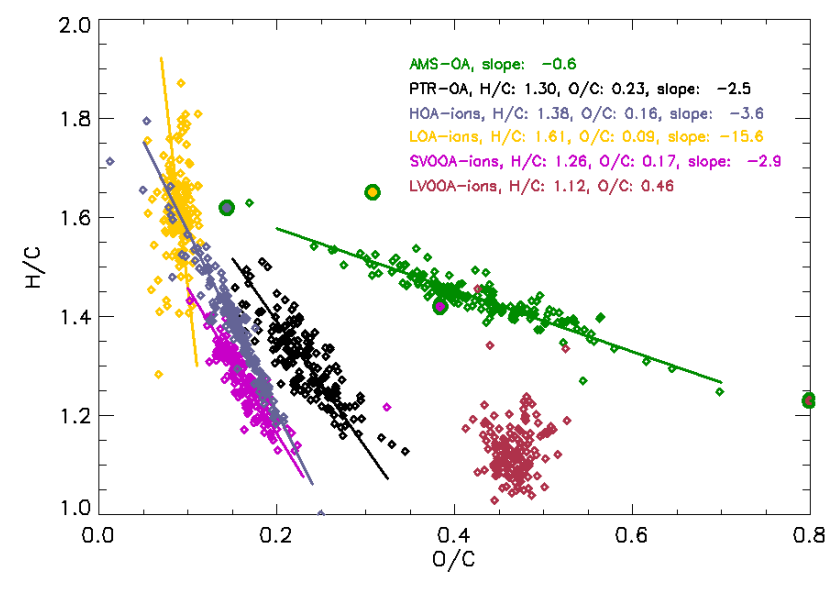

Fig. 7. Scatter plot of the atomic ratios $\mathrm{O} / \mathrm{C}$ and $\mathrm{H} / \mathrm{C}$ (van Krevelen diagram) of AMS-OA, PTR-OA and the sub-fractions of ions correlating best with HOA, LOA, SV-OOA, and LV-OOA, respectively. The color-coded green circles represent the mean $\mathrm{O} / \mathrm{C}$ and $\mathrm{H} / \mathrm{C}$ ratio of HOA (grey), LOA (yellow), SV-OOA (magenta), and LV-OOA (brown) as derived from PMF analysis of AMS data.

$\overline{\mathrm{OS}_{\mathrm{C}}}$ values). The location of the subgroups of PTR-OA in the $\overline{n_{\mathrm{C}}}-\overline{\mathrm{OS}_{\mathrm{C}}}$ space is generally consistent with this picture: the primary fractions (HOA-ions and LOA-ions) are located close to the left bottom corner, the more aged SV-OOA-ions occupy a region more towards the center, and the LV-OOAions representing the most aged fraction of $\mathrm{OA}$ are near the right top corner in Fig. 6.

Note that the $\overline{n_{\mathrm{C}}}$ and $\overline{\mathrm{OS}_{\mathrm{C}}}$ values presented here is influenced by molecular changes during analysis. Thermal decomposition on the CTD cell produces species with fewer carbon atoms than the parent compounds that are part of OA. The same holds for compounds that fragment during ionization in the PTR - the detected ion will have fewer carbon atoms than the parent compound. Both processes result in $\overline{n_{\mathrm{C}}}$ values that are too low. Similarly the production of undetectable highly oxidized species $\left(\mathrm{CO}_{2}, \mathrm{H}_{2} \mathrm{O}\right)$ from thermal decomposition or fragmentation would result in $\overline{\mathrm{OS}_{\mathrm{C}}}$ values that are calculated too low. Accurate correction of these biases requires more systematic investigation of the loss processes and will be investigated in the future.

Linear regressions of PTR-OA and the ions representing HOA, LOA, and SV-OOA have been calculated according to the method described by Press and Teukolsky (1992), which considers error in both coordinates. This analysis reveals that the primary HOA component follows the steepest slope of -0.16 (Fig. 6). The slope in the $\overline{n_{\mathrm{C}}}-\overline{\mathrm{OS}_{\mathrm{C}}}$ space characterizes the chemistry that acts on OA or a OA-component. A shallow slope is consistent with chemical fragmentation (i.e. the cleavage of C-C bonds as a result of oxidation that moves organics along a horizontal line in the $\overline{n_{\mathrm{C}}}-\overline{\mathrm{OS}_{\mathrm{C}}}$ space; NOT to be confused with fragmentation in the PTR as discussed above) dominating over functionalization (i.e. the addition of 

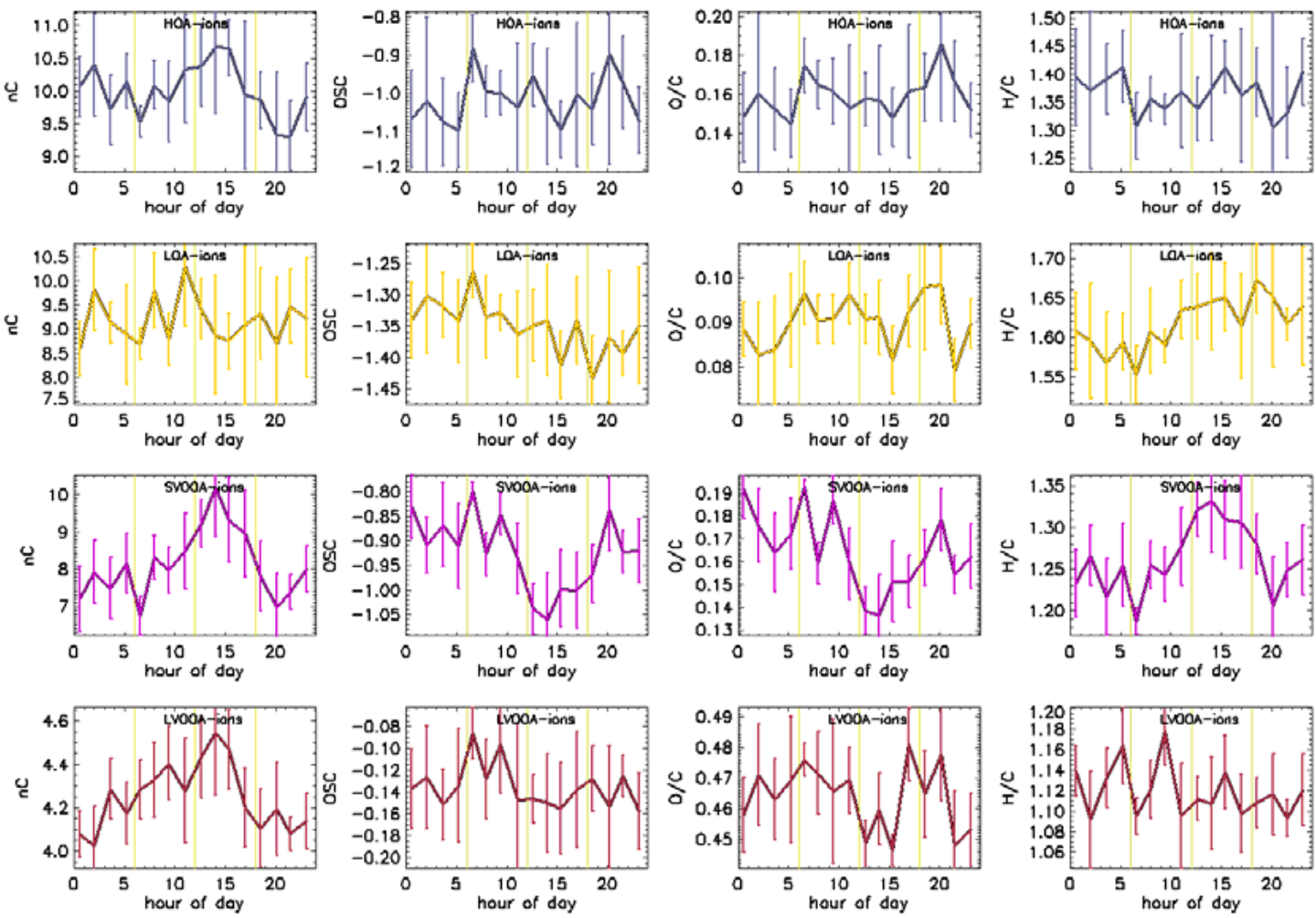

Fig. 8. Campaign-median diurnal variation of the chemical parameters $\overline{n_{\mathrm{C}}}, \overline{\mathrm{OS}_{\mathrm{C}}}, \mathrm{O} / \mathrm{C}$, and $\mathrm{H} / \mathrm{C}$ of the sub-fractions of ions correlating best with HOA, LOA, SV-OOA, and LV-OOA, respectively. The vertical bars represent the standard deviation of the data in the respective time-bin. Note that the two most outlying data points have been removed in every time-bin.

oxygen functional groups that moves organics along a vertical line in the $\overline{n_{\mathrm{C}}}-\overline{\mathrm{OS}_{\mathrm{C}}}$ space). The steeper slope suggests that functionalization is more important for primary HOA. The shallower slope of ions representing SV-OOA $(-0.06)$ suggests that chemical fragmentation becomes more important as OA ages. The shallow slope of PTR-OA $(-0.07)$ indicates that chemical fragmentation dominates the chemistry that is eventually producing LV-OOA. The sequence of decreasing slopes is not unexpected: by adding oxygen functional groups to the carbon skeleton electrons are withdrawn from carbon atoms thereby weakening neighboring C-C bonds (Atkinson, 2007). Therefore, it can be expected that chemical fractionation becomes dominant when aerosol compounds are more and more oxidized. While the sequence of decreasing slopes is in accordance with the understanding of chemistry, the above mentioned biases caused by thermal decomposition and fragmentation in the PTR hamper a more quantitative analysis at this moment. The group of ions representing LV-OOA actually occupies a very limited area in both coordinates, $\overline{n_{\mathrm{C}}}$ and $\overline{\mathrm{OS}_{\mathrm{C}}}$. This may indicate that there are limits to further oxidation of LV-OOA. The most likely reason is that the oxidation of LV-OOA produces volatile organics that do not stay in the particle phase; however, also instrumental limitations cannot be excluded at this point.
The median diurnal variation of $\overline{n_{\mathrm{C}}}$ and $\overline{\mathrm{OS}_{\mathrm{C}}}$ is shown in the first two columns of Fig. 8. The most outstanding feature is the increase of $\overline{n_{\mathrm{C}}}$ by more than 2 between $6 \mathrm{a} . \mathrm{m}$. and 3 p.m. local time for SV-OOA-ions. During the same period $\overline{\mathrm{OS}_{\mathrm{C}}}$ significantly decreased and the total mass of SVOOA-ions increased by a factor of 3 (Fig. 3j). This is somewhat counterintuitive at first sight because the course of $\overline{n_{\mathrm{C}}}$ and $\overline{\mathrm{OS}_{\mathrm{C}}}$ suggest that $\mathrm{SV}-\mathrm{OOA}$ is becoming photochemically less aged during the time of the highest photochemical activity. However, large quantities of SV-OOA are produced during the same period from a pool of gas phase precursor compounds. During daytime these gas phase precursors are oxidized to form semivolatile compounds that condense on particles. So, the "rejuvenation" of SV-OOA during daytime reflects the production of new SV-OOA mass. Photochemical ageing dominated after 3 p.m. and resulted in decreasing $\overline{n_{\mathrm{C}}}$ and increasing $\overline{\mathrm{OS}_{\mathrm{C}}}$ values. Similar rejuvenation during daytime (but less clear) was also observed for HOA- and LVOOA-ions, however, without the large increase in concentration that is evident for SV-OOA. Nevertheless this may mean that during daytime the production of new SOA mass dominates over chemical ageing for these OA components. No clear diurnal trend can be seen for the group of ions best correlating with LOA. 
Another commonly used metric to explore chemical processing of $\mathrm{OA}$ is the representation of the atomic ratios $\mathrm{O} / \mathrm{C}$ and $\mathrm{H} / \mathrm{C}$ in a van Krevelen diagram (Fig. 7). Both, $\mathrm{H} / \mathrm{C}$ and $\mathrm{O} / \mathrm{C}$ are measured by PTR and AMS. The lower $\mathrm{H} / \mathrm{C}$ and $\mathrm{O} / \mathrm{C}$ values in Fig. 7 show that PTR-OA is depleted in both, $\mathrm{H}$ and $\mathrm{O}$ atoms. Also the atomic ratios of the different groups are generally below the average values obtained from the $\mathrm{PMF}$ analysis of AMS data. The only exception is the $\mathrm{O} / \mathrm{C}$ ratio of HOA-ions $(0.16)$ that is similar to the average $\mathrm{O} / \mathrm{C}$ of HOA (0.14). Above we argued that the low abundance of ions with $m / z<100$ may reflect that thermal dissociation is less important for HOA. Accordingly it can be argued that thermal decomposition represents the largest loss for oxygen and fragmentation in the PTR does not cause a strong bias in $\mathrm{O} / \mathrm{C}$. The lower $\mathrm{H} / \mathrm{C}$ of HOA-ions may reflect the fact that PTR-OA partially excludes the contribution from alkanes.

$\mathrm{Ng}$ et al. (2011) and Hayes et al. (2013) observe that the slope of HOA in the van Krevelen graph during aging should be approximately -2 . The HOA-ions follow a steeper slope of -3.6 and it is currently not clear which processes force the steeper slope of these ions. This fact hampers the extended use of the linear regressions in the van Krevelen graph that have been associated with broad chemical pathways (Heald et al., 2010).

The diurnal variation of $\mathrm{O} / \mathrm{C}$ and $\mathrm{H} / \mathrm{C}$ is shown in the 3rd and 4th column in Fig. 8 for HOA-, LOA-, SV-OOA-, and LV-OOA-ions. The $\mathrm{O} / \mathrm{C}$ ratio decreases during the period 6 a.m.-2 p.m. for SV-OOA ions while their $\mathrm{H} / \mathrm{C}$ ratio increases. This reflects again the large production of SV-OOA during the day hours as discussed above. Diurnal variations in $\mathrm{O} / \mathrm{C}$ and $\mathrm{H} / \mathrm{C}$ of the other ion groups are not significant and/or hard to interpret.

\subsection{Nitrogen content of $\mathrm{OA}$}

Based on the empirical formulas we calculated atomic N/C ratios for PTR-OA and the subgroups of HOA-, LOA-, SVOOA-, and LVOOA-ions. Note that according to the rules outlined above we always selected the non-nitrogen option in cases where several possible empirical formulas could be attributed to a mass peak. Therefore the calculated $\mathrm{N} / \mathrm{C}$ ratios should represent a lower limit.

For PTR-OA we calculate a mean $\mathrm{N} / \mathrm{C}$ ratio of $2.6 \%$ and the values for the 10,50 , and $90 \%$ percentiles are $1.7,2.4$, and $3.3 \%$, respectively. The corresponding values for AMS-OA are 0.9, 0.6, 0.9, and $1.4 \%$, respectively. If we consider only data above the $80 \%$ percentile the mean concentration of PTR-OA was $8.2 \mu \mathrm{g} \mathrm{m}^{-3}$. During the same periods the AMS measured a mean concentration of $12.1 \mathrm{\mu g} \mathrm{m}^{-3}$, and the derived average empirical formulas were $\mathrm{CH}_{1.34} \mathrm{O}_{0.22} \mathrm{~N}_{0.023}{ }^{2}$ (PTR) and $\mathrm{CH}_{1.45} \mathrm{O}_{0.43} \mathrm{~N}_{0.011}$ (AMS). This translates to concentrations of $0.16 \mu \mathrm{gN} \mathrm{m}^{-3}$

\footnotetext{
${ }^{2}$ Note that atom fractions of $\mathrm{H}, \mathrm{O}$, and $\mathrm{N}$ in these average formulas are an exact equivalent to the atomic ratios $\mathrm{H} / \mathrm{C}, \mathrm{O} / \mathrm{C}$, and $\mathrm{N} / \mathrm{C}$.
}

(i.e. $1.9 \%$ of $8.2 \mu \mathrm{g} \mathrm{m}^{-3}$ ) and $0.10 \mu \mathrm{gN} \mathrm{m}^{-3}$ (i.e. $0.8 \%$ of $12.1 \mathrm{\mu g} \mathrm{m}^{-3}$ ) detected by PTR and AMS, respectively. The difference between PTR and AMS is within the $30 \%$ uncertainty of both instruments; however, as will be discussed below, we speculate that the difference may be meaningful. Extending this analysis to the OA components reveals that the difference between the AMS and PTR nitrogen concentrations much larger for HOA and LV-OOA: the PTR measured $0.047 \mu \mathrm{gN} \mathrm{m}^{-3}$ (HOAions, $\left.1.9 \mu \mathrm{g} \mathrm{m}^{-3}, \mathrm{CH}_{1.39} \mathrm{O}_{0.16} \mathrm{~N}_{0.030}\right)$ and $0.064 \mu \mathrm{gN} \mathrm{m}^{-3}$ (LVOOA-ions, $1.7 \mu \mathrm{g} \mathrm{m}^{-3}, \mathrm{CH}_{1.11} \mathrm{O}_{0.45} \mathrm{~N}_{0.058}$ ), which is $\sim 3$ times more than the corresponding AMS values (0.016 and $0.22 \mu \mathrm{gN} \mathrm{m}^{-3}$ based on $\mathrm{CH}_{1.62} \mathrm{O}_{0.144} \mathrm{~N}_{0.01}$ and $\mathrm{CH}_{1.23} \mathrm{O}_{0.799} \mathrm{~N}_{0.012}$ for HOA and LV-OOA, respectively).

Considering the above discussed losses of carbon, oxygen and hydrogen in the PTR it is very likely that also nitrogen is lost. For example, ionization of alkyl-nitrates in the PTR often produces a neutral nitric acid fragment and an alkyl ion that is detected by the mass spectrometer, or an $\mathrm{NO}_{2}^{+}$ion and a neutral organic fragment, although some protonated nitrate ions are also detected (Aoki et al., 2007). As a result the nitrogen contained in such compounds will be underestimated, as the $\mathrm{NO}_{2}^{+}$ion is treated as inorganic in the PTR (similarly to the AMS). Thermal decomposition of nitrogen compounds in the CTD-cell may produce inorganic molecules such as $\mathrm{NH}_{3}$, $\mathrm{HNO}_{3}$, or $\mathrm{N}_{2} \mathrm{O}$ that are either not detected or treated as inorganic in the PTR, thus representing a loss of organic N. Such loss mechanisms are not properly quantified yet and cannot be properly corrected for the PTR. If such correction factors become available in the future, $\mathrm{N}$-concentrations measured by PTR will likely be higher. Therefore, we consider it very likely that the difference between PTR and AMS might be significant and that there is an unconsidered artifact in either the PTR or the AMS.

Another source of uncertainty is the assignment of empirical formulas, which is uncertain for many ions due to the limited mass resolving power of the mass spectrometer. For nitrogen the uncertainty is probably a factor 3 or more. However, we were very conservative in assigning nitrogen species and therefore we think that the calculated $\mathrm{N} / \mathrm{C}$ ratios are likely to be close to the lower end of the possible range of $\mathrm{N} / \mathrm{C}$ ratios.

On the other hand, an underestimation of $\mathrm{N}$ by the AMS, other than from organic nitrates, is inconsistent with our current understanding of $\mathrm{N}$-species detection in this instrument. The AMS may miss organic nitrates that fragment to $\mathrm{NO}^{+}$ and $\mathrm{NO}_{2}^{+}$ions that are treated as inorganic in most AMS field analyses (Farmer et al., 2010), while other N-containing species are thought to be detected quantitatively and with little variation in detection efficiency for different functional groups (Aiken et al., 2008). A possible explanation is that larger organic nitrates that would be expected to be present in the aerosol may decompose less in the PTR than the $\mathrm{C}_{1}-\mathrm{C}_{5}$ alkyl nitrates studied by Aoki et al. (2007), and thus that the difference can be partially explained by the stronger under 

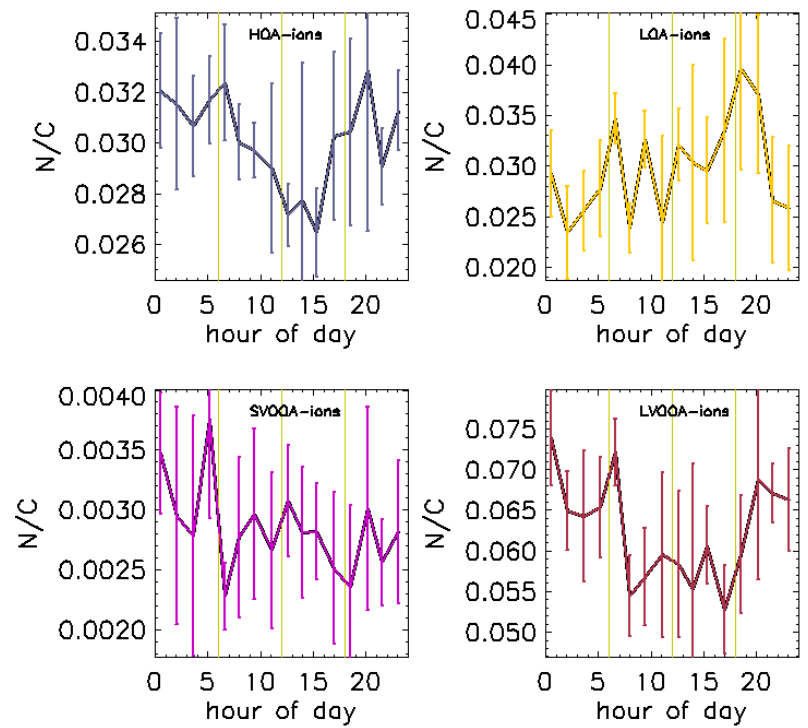

Fig. 9. Diurnal variation of atomic N/C ratios for the ion groups best correlating with HOA, LOA, SV-OOA, and LV-OOA.

detection of organic nitrate $\mathrm{N}$ by the AMS. However, semivolatile organic nitrates are produced by gas phase chemistry and are expected to be part of SV-OOA. So, the very low $\mathrm{N}$-content of SVOOA-ions (see below) does not support this idea.

\subsection{Nitrogen chemistry as source of $\mathrm{OA}$ components}

Figure 9 shows the diurnal variation of N/C for HOA-, LOA-, SVOOA-, and LVOOA-ions. Data treatment was the same as for the data shown in Fig. 8. Figure 10 shows N/C as a function of CTD-cell temperature for the same ion groups. The atomic N/C ratio of LVOOA-ions (median $6.4 \%$ ) is about twice as high as $\mathrm{N} / \mathrm{C}$ of the primary components HOA-, and LOA-ions (median 3.0 and $2.9 \%$, respectively), and $\sim 20$ times higher the N/C of SVOOA-ions (median $0.3 \%$ ). The latter value may be biased because SV-OOAions account only for a $\sim 5 \%$ of SV-OOA (Fig. $3 \mathrm{~d}$ and j). As discussed above the group of SVOOA-ions becomes much larger ( $\sim 35 \%$ of SV-OOA) if AMS-OA is excluded from the correlation analysis. However, N/C still remains below $1 \%$ in this case and only slightly different values are calculated for the other ion groups. Thus, the high nitrogen content of LV-OOA-ions cannot be explained by photochemical ageing of SV-OOA. The accumulation of nitrogen in the low volatile component of OA excludes gas phase nitrogen chemistry with subsequent partitioning into the particle phase as source of these compounds. Instead we suggest that the compounds carrying the nitrogen are produced by multiphase chemistry. Ammonium ions in the liquid phase of particles may play an important role, which is also supported by many empirical formulas of N-containing LVOOA-ions. Many of

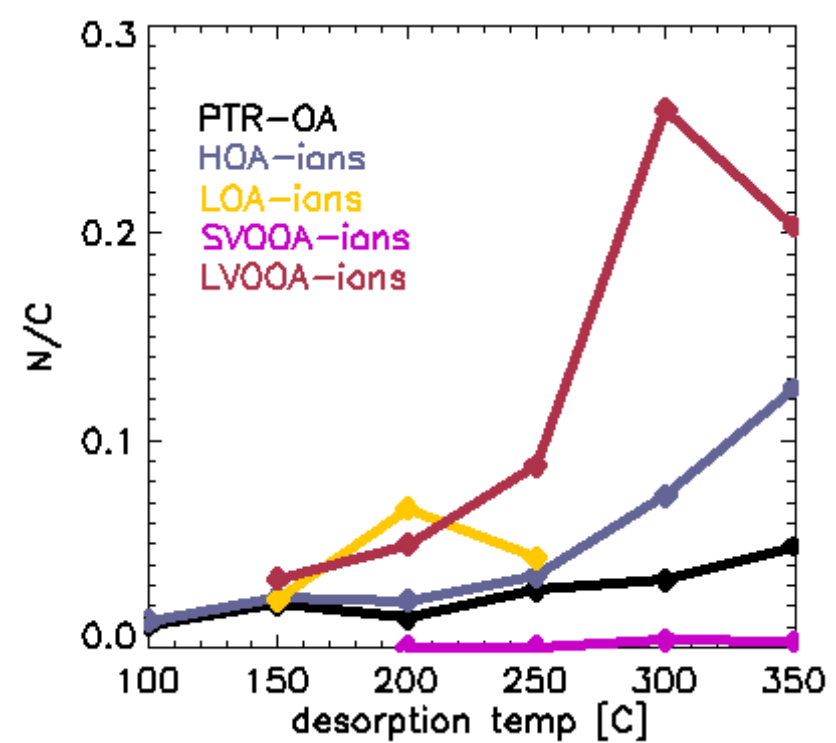

Fig. 10. Atomic N/C ratios as a function of the desorption temperature for PTR-OA and the ion groups best correlating with HOA, LOA, SV-OOA, and LV-OOA.

these ions are rather saturated and/or only moderately oxidized or not oxidized at all (Table A5). Our finding is in agreement with a laboratory studies that showed the importance of organic ammonium salt formation as source of SOA (e.g. Dinar et al., 2008; Na et al., 2007; o'Brien et al., 2013; Zhao et al., 2013). The higher N/C values of LVOOA-ions during night may reflect a larger chemical age with respect to multiphase chemistry, consistent with the larger aerosol water content at night. Nitrogen compounds in the group of HOA-ions may reflect primary nitrogen compounds and the lower N/C ratios during daytime may be due lower partitioning into the particle phase during the day when the temperatures are higher. However, higher N/C values at higher desorption temperatures in the group of HOA-, and LVOOAions suggests that $\mathrm{N}$-containing compounds are typically less volatile (Fig. 10), which is in conflict with the idea of temperature driven gas-particle partitioning of $\mathrm{N}$-compounds in the group of HOA-ions. Therefore, the diurnal cycle of N/C for HOA-ions is currently not well understood.

\section{Conclusions}

We presented an evaluation of the chemical composition of organic aerosol as measured with TD-PTR-MS at the CalNex ground site in Pasadena during summer 2010. Comparison of PTR-OA with the total concentration of OA measured with AMS shows that PTR directly detects $25-60 \%$ of OA. Several potential reasons for the difference have been discussed, and the largest factors accounting for the difference between PTR-OA and OA are considered to be undetectable products 
from thermal dissociation on the CTD-cell and fragmentation in the PTR-MS.

A correlation analysis with OA components was performed to establish groups of ions that represent hydrocarbon-like OA (HOA), local OA (LOA), semi-volatile and low volatility oxygenated OA (SV-OOA, and LV-OOA). The average mass spectra and thermograms of these groups of ions show that (i) HOA- and LOA-ions include the highest $m / z$ ratios and are most volatile, SV-OOA-ions do not include masses above $m / z 350$ and are least volatile, and (iii) LV-OOA-ions do not include ions above $m / z 230$ and desorb at lower temperatures than SV-OOA-ions (but higher than HOA- and LOA-ions). This is consistent with LOA- and HOA-ions being primary aerosol, SV-OOA- and LV-OOAions being more aged. LV-OOA-ions are most likely predominantly products of thermal dissociation on the CTD-cell.

Representing the ion groups on a $\overline{n_{\mathrm{C}}}$ (mean carbon number) versus $\overline{\mathrm{OS}_{\mathrm{C}}}$ (mean carbon oxidation state) diagram shows that the correlation analysis produced ion groups that occupy district regions in this diagram, which is consistent with the photochemical age of HOA, LOA, SV-OOA, and LV-OOA. Linear regression of $\overline{n_{\mathrm{C}}}$ and $\overline{\mathrm{OS}_{\mathrm{C}}}$ produced slopes demonstrating that chemical fragmentation (C-C bond cleavage) gains importance over functionalization (addition of oxygen functional groups) as aerosol ageing proceeds. Surprisingly, the photochemical age of OA decreases during the middle of the day. This can be understood in the light of large production of new SV-OOA during daytime.

The TD-PTR-MS measured higher concentrations of nitrogen in OA than the AMS, the reasons for which are not understood, however it is hard to explain this by artifacts related to PTR because the known artifacts result in under detection of $\mathrm{O}, \mathrm{C}$, and $\mathrm{H}$; therefore an opposite effect for $\mathrm{N}$ is not plausible. Similarly a large underestimation of $\mathrm{N}$ for species other than organic nitrates is inconsistent with current understanding of the AMS. Future studies should further explore this question. The median PTR N/C ratio is 6.4, 3.0, 2.9 , and $<1 \%$ for LVOOA-, HOA-, LOA-, and SVOOA-ions, respectively. The high nitrogen content of LV-OOA suggests that a multiphase chemical source is contributing to this component involving ammonium in the liquid phase of aerosols.

\section{Supplementary material related to this article is available online at http://www.atmos-chem-phys.net/13/ 10125/2013/acp-13-10125-2013-supplement.zip.}

\section{Appendix A}

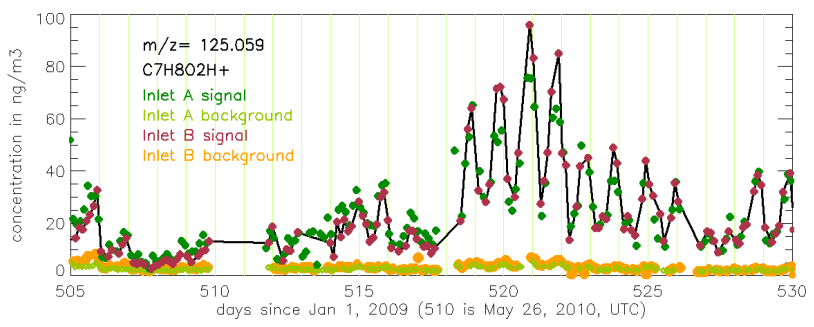

Fig. A1. Total concentration detected at $m / z$ 125.059 Da. The background concentration is measured by sampling through a particle filter. Most species exhibit similarly low and constant background levels as $m / z$ 125.059.

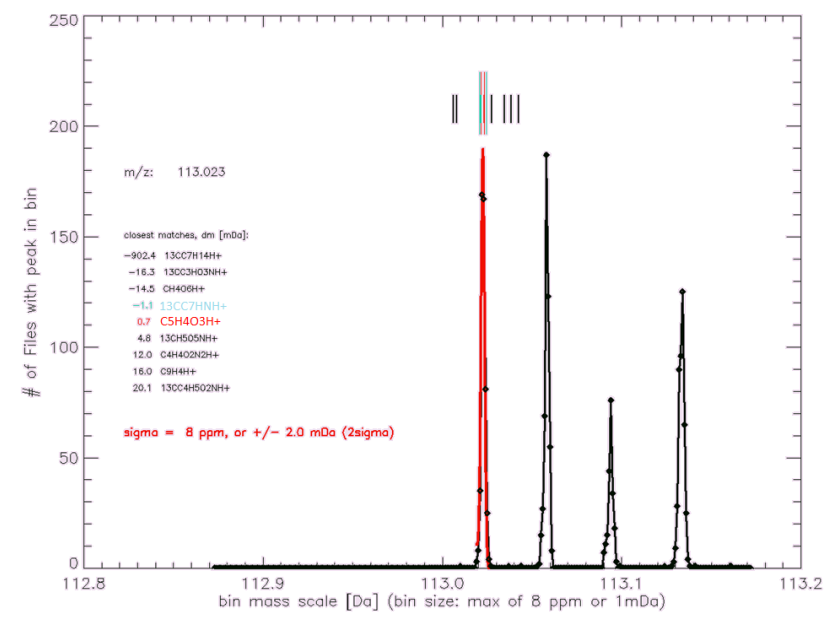

Fig. A2. Histogram of detected peaks in $\sim 500$ individual files (900 five second mass spectra, $75 \mathrm{~min}$ of data per file) around $113 \mathrm{Da}$. The mass scale consist of $8 \mathrm{ppm}$ bins (or $1 \mathrm{mDa}$ bins if $8 \mathrm{ppm}<1 \mathrm{mDa}$, i.e. below $125 \mathrm{Da}$ ). The precision of the measured $\mathrm{m} / \mathrm{z}$ ratio is defined as 2 times sigma of a Gaussian fit (red line). All empirical formulas of library matches within $\pm 2 \sigma$ of the measured $m / z$ are initially attributed to the $m / z$ signal. These are $\mathrm{C}_{5} \mathrm{H}_{4} \mathrm{O}_{3} \mathrm{H}^{+}$ and ${ }^{13} \mathrm{CC}_{7} \mathrm{HNH}^{+}$for the example shown in the figure, however, ${ }^{13} \mathrm{CC}_{7} \mathrm{HNH}^{+}$has been dismissed because this species is not consistent with the expected signal of the parent compound at 112.020 Da. The short vertical lines above the peak $(m / z=113.023)$ indicate the $m / z$ of potential library matches listed left in the chart area. The longer vertical lines indicate the 1-sigma (red) and 2-sigma (cyan) boundaries around the peak. 
Acknowledgements. The authors thank Jochen Stutz, John Seinfeld and Joost de Gouw for their leadership in organizing the Pasadena ground site, and CARB and NOAA for support of the site setup. The TD-PTR-MS has been funded by The Netherlands Organization for Scientific Research (NWO) under the ALW-Middelgroot program (Grant 834.08.002). RH, JT, and AHG acknowledge support from NSF Atmospheric Chemistry Program award 0931934 for performing the field work during CalNex-LA. JLJ and PLH acknowledge support from CARB 08-319 and CARB 11-305 as well as DOE (BER, ASR Program) DE-SC0006035. PLH also acknowledges a fellowship from the CIRES Visiting Fellows Program.

Edited by: J. H. Seinfeld

\section{References}

Aiken, A. C., Decarlo, P. F., Kroll, J. H., Worsnop, D. R., Human, J. A., Docherty, K. S., Ulbrich, I. M., Mohr, C., Kimmel, J. R., Sueper, D., Sun, Y., Zhang, Q., Trimborn, A., Northway, M., Ziemann, P. J., Canagaratna, M. R., Onasch, T. B., Alfarra, M. R., Prevot, A. S. H., Dommen, J., Duplissy, J., Metzger, A., Baltensperger, U., and Jimenez, J.: O/C and OM/OC ratios of primary, secondary, and ambient organic aerosols with high-resolution time-of-flight aerosol mass spectrometry, Environ. Sci. Technol., 42, 4478-4485, 2008.

Andreae, M. O., Jones, C. D., and Cox, P. M.: Strong present-day aerosol cooling implies a hot future, Nature, 435, 1187-1190, 2005.

Aoki, N., Inomata, S., and Tanimoto, H.: Detection of C-1-C-5 alkyl nitrates by proton transfer reaction time-of-flight mass spectrometry, Int. J. Mass Spectrom., 263, 12-21, 2007.

Atkinson, R.: Rate constants for the atmospheric reactions of alkoxy radicals: an updated estimation method. Atmos. Environ. 41, 8468-8485, 2007.

DeCarlo, P. F., Kimmel, J. R., Trimborn, A., Northway, M. J., Jayne, J. T., Aiken, A. C., Gonin, M., Fuhrer, K., Horvath, T., Docherty, K. S., Worsnop, D. R., and Jimenez, J. L.: Field-Deployable, High-Resolution, Time-of-Flight Aerosol Mass Spectrometer, Anal. Chem., 78, 8281-8289, 2006.

Dinar, E., Anttila, T., and Rudich, Y.: CCN activity and hygroscopic growth of organic aerosols following reactive uptake of ammonia, Environ. Sci. Technol., 42, 793-799, 2008.

Docherty, K. S., Huffman, J. A., and Jimenez, J. L.: Effect of Vaporizer Temperature on Ambient High-Resolution Time-of-Flight Aerosol Mass Spectrometer Organic Mass Spectra, 27th Annual Conference of the American Association for Aerosol Research, Orlando, Florida, October 2008.

Donahue, N. M., Robinson, A. L., Stanier, C. O., and Pandis, S. N.: Coupled partitioning, dilution, and chemical aging of semivolatile organics, Environ. Sci. Technol., 40, 2635-2643, 2006.

Dzepina, K., Volkamer, R. M., Madronich, S., Tulet, P., Ulbrich, I. M., Zhang, Q., Cappa, C. D., Ziemann, P. J., and Jimenez, J. L.: Evaluation of recently-proposed secondary organic aerosol models for a case study in Mexico City, Atmos. Chem. Phys., 9, 5681-5709, doi:10.5194/acp-9-5681-2009, 2009.

Ervens, B., Turpin, B. J., and Weber, R. J.: Secondary organic aerosol formation in cloud droplets and aqueous parti- cles (aqSOA): a review of laboratory, field and model studies, Atmos. Chem. Phys., 11, 11069-11102, doi:10.5194/acp-1111069-2011, 2011.

Farmer, D. K., Matsunaga, A., Docherty, K. S., Surratt, J. D., Seinfeld, J. H., Ziemann, P. J., and Jimenez, J. L.: Response of an aerosol mass spectrometer to organonitrates and organosulfates and implications for atmospheric chemistry, P. Natl. Acad. Sci. USA, 107, 6670-6675, 2010.

Galloway, M. M., Chhabra, P. S., Chan, A. W. H., Surratt, J. D., Flagan, R. C., Seinfeld, J. H., and Keutsch, F. N.: Glyoxal uptake on ammonium sulphate seed aerosol: reaction products and reversibility of uptake under dark and irradiated conditions, Atmos. Chem. Phys., 9, 3331-3345, doi:10.5194/acp-9-3331-2009, 2009.

Goldstein, A. H. and Galbally, I. E.: Known and unexplored organic constituents in the earth's atmosphere, Environ. Sci. Technol., 41, 1514-1521, 2007.

Guenther, A., Karl, T., Harley, P., Wiedinmyer, C., Palmer, P. I., and Geron, C.: Estimates of global terrestrial isoprene emissions using MEGAN (Model of Emissions of Gases and Aerosols from Nature), Atmos. Chem. Phys., 6, 3181-3210, doi:10.5194/acp-63181-2006, 2006.

Hallquist, M., Wenger, J. C., Baltensperger, U., Rudich, Y., Simpson, D., Claeys, M., Dommen, J., Donahue, N. M., George, C., Goldstein, A. H., Hamilton, J. F., Herrmann, H., Hoffmann, T., Iinuma, Y., Jang, M., Jenkin, M. E., Jimenez, J. L., Kiendler-Scharr, A., Maenhaut, W., McFiggans, G., Mentel, Th. F., Monod, A., Prévôt, A. S. H., Seinfeld, J. H., Surratt, J. D., Szmigielski, R., and Wildt, J.: The formation, properties and impact of secondary organic aerosol: current and emerging issues, Atmos. Chem. Phys., 9, 5155-5236, doi:10.5194/acp-9-51552009, 2009.

Hayes, P. L., Ortega, A. M., Cubison, M. J., Hu, W. W., Toohey, D. W., Flynn, J. H., Lefer, B. L., Grossberg, N., Alvarez, S., Rappenglück, B., Taylor, J. W., Allan, J. D., Holloway, J. S., Gilman, J. B., Kuster, W. C., de Gouw, J. A., Massoli, P., Zhang, X., Liu, J., Weber, R. J., Corrigan, A. L., Russell, L. M., Zhao, Y., Cliff, S. S., Isaacman, G., Worton, D. R., Kreisberg, N. M., Hering, S. V., Goldstein, A. H., Thalman, R., Waxman, E. M., Volkamer, R., Lin, Y. H., Surratt, J. D., Kleindienst, T. E., Offenberg, J. H., Froyd, K. D., Dusanter, S., Griffith, S., Stevens, P. S., Brioude, J., Angevine, W. M., and Jimenez, J. L.: Organic aerosol composition and sources in Pasadena, California during the 2010 CalNex campaign, J. Geophys. Res.-Atmos., 118, 9233-9257, doi:10.1002/jgrd.50530, 2013.

Heald, C. L., Kroll, J. H., Jimenez, J. L., Docherty, K. S., DeCarlo, P. F., Aiken, A. C., Chen, Q., Martin, S. T., Farmer, D. K., and Artaxo, P.: A simplified description of the evolution of organic aerosol composition in the atmosphere, Geophys. Res. Lett., 37, L08803, doi:10.1029/2010GL042737, 2010.

Heald, C. L., Coe, H., Jimenez, J. L., Weber, R. J., Bahreini, R., Middlebrook, A. M., Russell, L. M., Jolleys, M., Fu, T.-M., Allan, J. D., Bower, K. N., Capes, G., Crosier, J., Morgan, W. T., Robinson, N. H., Williams, P. I., Cubison, M. J., DeCarlo, P. F., and Dunlea, E. J.: Exploring the vertical profile of atmospheric organic aerosol: comparing 17 aircraft field campaigns with a global model, Atmos. Chem. Phys., 11, 12673-12696, doi:10.5194/acp-11-12673-2011, 2011. 
Hodzic, A., Jimenez, J. L., Madronich, S., Canagaratna, M. R., DeCarlo, P. F., Kleinman, L., and Fast, J.: Modeling organic aerosols in a megacity: potential contribution of semi-volatile and intermediate volatility primary organic compounds to secondary organic aerosol formation, Atmos. Chem. Phys., 10, 5491-5514, doi:10.5194/acp-10-5491-2010, 2010.

Holzinger, R., Williams, J., Herrmann, F., Lelieveld, J., Donahue, N. M., and Röckmann, T.: Aerosol analysis using a ThermalDesorption Proton-Transfer-Reaction Mass Spectrometer (TDPTR-MS): a new approach to study processing of organic aerosols, Atmos. Chem. Phys., 10, 2257-2267, doi:10.5194/acp10-2257-2010, 2010a.

Holzinger, R., Kasper-Giebl, A., Staudinger, M., Schauer, G., and Röckmann, T.: Analysis of the chemical composition of organic aerosol at the Mt. Sonnblick observatory using a novel high mass resolution thermal-desorption proton-transfer-reaction mass-spectrometer (hr-TD-PTR-MS), Atmos. Chem. Phys., 10, 10111-10128, doi:10.5194/acp-10-10111-2010, 2010 b.

Huffman, J. A., Docherty, K. S., Aiken, A. C., Cubison, M. J., Ulbrich, I. M., DeCarlo, P. F., Sueper, D., Jayne, J. T., Worsnop, D. R., Ziemann, P. J., and Jimenez, J. L.: Chemically-resolved aerosol volatility measurements from two megacity field studies, Atmos. Chem. Phys., 9, 7161-7182, doi:10.5194/acp-9-71612009, 2009.

IPCC: Summary for Policymakers, in: Climate Change 2007: Impacts, Adaptation and Vulnerability. Contribution of Working Group II to the Fourth Assessment Report of the Intergovernmental Panel on Climate Change, edited by: Parry, M. L., Canziani, O. F., Palutikof, J. P., van der Linden, P. J., and Hanson, C. E., Cambridge University Press, Cambridge, UK, 7-22, 2007.

Jakober, C. A., Robert, M. A., Riddle, S. G., Destaillats, H., Charles, M. J., Green, P. G., and Kleeman, M.: Carbonyl Emissions from Gasoline and Diesel Motor Vehicles, Environ. Sci. Technol., 42, 4697-4703, doi:10.1021/es7029174, 2008.

Jayne, J. T., Leard, D. C., Zhang, X. F., Davidovits, P., Smith, K. A., Kolb, C. E., and Worsnop, D. R.: Development of an aerosol mass spectrometer for size and composition analysis of submicron particles, Aerosol Sci. Technol., 33, 49-70, 2000.

Jimenez, J. L., Cocker, D. R., Bahreini, R., Zhuang, H., Varutbangkul, V., Flagan, R. C., Seinfeld, J. H., Hoffmann, T., and O'Dowd, C.: New Particle Formation from Photooxidation of Diiodomethane (CH2I2), J. Geophys. Res.-Atmos., 108, 4318, doi:10.1029/2002JD002452, 2003.

Jobson, B. T., Alexander, M. L., Maupin, G. D., Muntean, G. G.: On-line analysis of organic compounds in diesel exhaust using a proton transfer reaction mass spectrometer (PTR-MS), Int. J. Mass Spectrom., 245, 78-89, doi:10.1016/j.ijms.2005.05.009, 2005.

Kalberer, M., Paulsen, D., Sax, M., Steinbacher, M., Dommen, J., Prevot, A. S. H., Fisseha, R., Weingartner, E., Frankevich, V., Zenobi, R., and Baltensperger, U.: Identification of polymers as major components of atmospheric organic aerosols, Science, 303, 1659-1662, 2004.

Kroll, J. H., Donahue, N. M., Jimenez, J. L., Kessler, S. H., Canagaratna, M. R., Wilson, K. R., Altieri, K. E., Mazzoleni, L. R., Wozniak, A. S., Bluhm, H., Mysak, E. R., Smith, J. D., Kolb, C. E., and Worsnop, D. R.: Carbon Oxidation State as a Metric for Describing the Chemistry of Atmospheric Organic Aerosol, Nature Chem., 3, 133-139, doi:10.1038/NCHEM.948, 2011.
Na, K., Song, C., Switzer, C., and Cocker III, D. R.: Effect of ammonia on secondary organic aerosol formation from -pinene ozonolysis in dry and humid conditions, Environ. Sci. Technol., 41, 6096-6102, 2007.

Ng, N. L., Canagaratna, M. R., Jimenez, J. L., Chhabra, P. S., Seinfeld, J. H., and Worsnop, D. R.: Changes in organic aerosol composition with aging inferred from aerosol mass spectra, Atmos. Chem. Phys., 11, 6465-6474, doi:10.5194/acp-11-64652011, 2011.

O’Brien, R. E., Laskin, A., Laskin, J., Liu, S., Weber, R., Russell, L. M., and Goldstein, A. H.: Molecular Characterization of Organic Aerosol Using Nanospray Desorption/Electrospray Ionization Mass Spectrometry: CalNex 2010 field study, Atmos. Environ., 68, 265-272, doi:10.1016/j.atmosenv.2012.11.056, 2013.

Paatero, P. and Tapper, U.: Positive Matrix Factorization - a Nonnegative Factor Model with Optimal Utilization of ErrorEstimates of Data Values, Environmetrics, 5, 111-126, 1994.

Pankow, J. F. and Asher, W. E.: SIMPOL.1: a simple group contribution method for predicting vapor pressures and enthalpies of vaporization of multifunctional organic compounds, Atmos. Chem. Phys., 8, 2773-2796, doi:10.5194/acp-8-27732008, 2008.

Press, W. H. and Teukolsky, S.: Fitting straight line data with errors in both coordinates, Comput. Phys., 6, 274-276, 1992.

Rollins, A. W., Browne, E. C., Min, K.-E., Pusede, S. E., Wooldridge, P. J., Gentner, D. R., Goldstein, A. H., Liu, S., Day, D. A., Russell, L. M., and Cohen, R. C.: Evidence for NOx Control over Nighttime SOA Formation, Science, 337, 1210, doi:10.1126/science.1221520, 2012.

Ryerson, T. B., Andrews, A. E., Angevine, W. M., Bates, T. S., Brock, C. A., Cairns, B., Cohen, R. C., Cooper, O. R., de Gouw, J. A., Fehsenfeld, F. C., Ferrare, R. A., Fischer, M. L., Flagan, R. C., Goldstein, A. H., Hair, J. W., Hardesty, R. M., Hostetler, C. A., Jimenez, J. L., Langford, A. O., McCauley, E., McKeen, S. A., Molina, L. T., Nenes, A., Oltmans, S. J., Parrish, D. D., Pederson, J. R., Pierce, R. B., Prather, K., Quinn, P. K., Seinfeld, J. H., Senff, C. J., Sorooshian, A., Stutz, J., Surratt, J. D., Trainer, M., Volkamer, R., Williams, E. J., and Wofsy, S. C.: The 2010 California Research at the Nexus of Air Quality and Climate Change (CalNex) field study, J. Geophys. Res.-Atmos., 118, 5830-5866, doi:10.1002/jgrd.50331, 2013.

Spracklen, D. V., Jimenez, J. L., Carslaw, K. S., Worsnop, D. R., Evans, M. J., Mann, G. W., Zhang, Q., Canagaratna, M. R., Allan, J., Coe, H., McFiggans, G., Rap, A., and Forster, P.: Aerosol mass spectrometer constraint on the global secondary organic aerosol budget, Atmos. Chem. Phys., 11, 12109-12136, doi:10.5194/acp-11-12109-2011, 2011.

Su, T. and Chesnavich, W. J.: Parameterization of the ion-polar molecule collision rate constant by trajectory calculations, J. Chem. Phys., 76, 5183-5185, 1982.

Sueper, D.: ToF-AMS Analysis Software, http://cires.colorado.edu/ jimenez-group/wiki/index.php/ToF-AMS_Analysis_Software, 2011.

Surratt, J. D., Gomez-Gonzalez, Y., Chan, A. W. H., Vermeylen, R., Shahgholi, M., Kleindienst, T. E., Edney, E. O., Offenberg, J. H., Lewandowski, M., Jaoui, M., Maenhaut, W., Claeys, M., Flagan, R. C., and Seinfeld, J. H.: Organosulfate formation in biogenic secondary organic aerosol, J. Phys. Chem. A, 112, 8345-8378, 2008. 
Ulbrich, I. M., Canagaratna, M. R., Zhang, Q., Worsnop, D. R., and Jimenez, J. L.: Interpretation of organic components from Positive Matrix Factorization of aerosol mass spectrometric data, Atmos. Chem. Phys., 9, 2891-2918, doi:10.5194/acp-9-2891-2009, 2009.

Volkamer, R., Martini, F. S., Molina, L. T., Salcedo, D., Jimenez, J. L., and Molina, M. J.: A missing sink for gas-phase glyoxal in Mexico City: Formation of secondary organic aerosol, Geophys. Res. Lett., 34, L19807 doi:10.1029/2007GL030752, 2007.
Zhao, Y., Kreisberg, N. M., Worton, D. R., Isaacman, G., Weber, R. J., Liu, S., Day, D. A., Russell, L. M., Markovic, M. Z., VandenBoer, T. C., Murphy, J. G., Hering, S. V., and Goldstein, A. H.: Insights into Secondary Organic Aerosol Formation Mechanisms from Measured Gas/Particle Partitioning of Specific Organic Tracer Compounds, Environ. Sci. Technol., doi:10.1021/es304587x, 2013. 